\title{
Tessere. Gli elementi costitutivi dell'immagine digitale tra arte, scienza e artigianato
}

\author{
Edoardo Dotto
}

Abstract

Laddove i progressi nel campo della tecnologia dell'immagine rendono disponibili monitor, schermi e touch-screen con risoluzione sempre maggiore - nei quali la misura di ogni singolo pixel sembra ridursi sino alla soglia della effettiva visibilità - la cultura visuale contemporanea, soprattutto nel campo ludico e videoludico, conserva ancora oggi uno spiccato interesse per tipologie di raffigurazione a bassa risoluzione in cui la riconoscibilità del singolo picture element costituisce il fondamento di ogni cifra estetica.

La storia della formazione delle immagini digitali - le cui origini si giovano di acquisizioni tardo ottocentesche nel campo dell'ottica e della pittura - si dipana tra gli anni Sessanta e Novanta del secolo scorso attraverso continui rimandi e contaminazioni tra le arti figurative e le più avanzate ricerche nel campo dell'informatica. Queste immagini di recente concezione, organizzate su fitte matrici di elementi quadrati, a ben vedere trovano addentellati nelle antiche tradizioni artigianali del mosaico ma ancor di più delle differenti tecnologie tessili le quali mostrano una strettissima analogia concettuale con le tecniche informatiche di supporto all'immagine.

Una riflessione che utilizzi il disegno come strumento per cogliere i legami tra queste immagini di natura diversa può rendere evidente come i più moderni low res media mostrino una connessione diretta con strutture visuali maturate attraverso la pratica manifatturiera.

Parole chiave

pixel, tessitura, mosaico, immagini digitali.
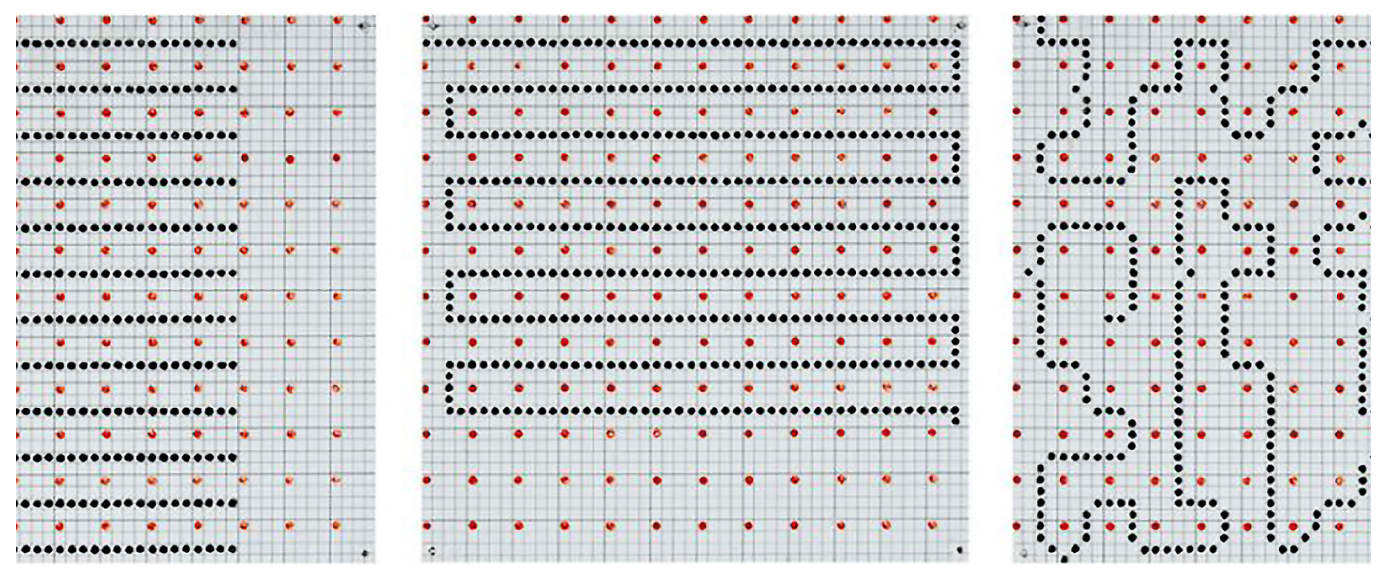


\section{Introduzione}

II tema generale del 'tessere' e del 'connettere' riferito all'ambito del disegno e - più in generale - della rappresentazione, si rivela come una occasione propizia per affrontare un tema che riguarda la struttura stessa delle immagini digitali. Come è noto, il tessuto che forma l'ossatura di un'immagine digitale è costituito da una fitta matrice di elementi quadrati, i picture elements o pixel, ciascuno dei quali è portatore di un'informazione elementare sulla porzione di immagine che occupa. Nella sua configurazione minima ciascun pixel può essere acceso o spento, e costituire l'elemento parziale di un'immagine in bianco e nero, in cui ogni sfumatura va resa con una sapiente mescolanza di quadratini scuri o luminosi. In generale, ciascun pixel è caratterizzato da un grado di informazione più complesso e può restituire un colore o un gradiente di grigio. L'accostamento di più pixel, specie se guardati da una distanza appropriata, consente di potere apprezzare un'immagine nella sua compiutezza, in modo tale che la tessitura di singoli elementi discreti venga trascurata a vantaggio della percezione di una figura continua in cui la matrice di elementi quadrati perde ogni rilevanza.

Come è ovvio, la sostituzione a livello percettivo dell'immagine 'discreta' - formata da elementi separati e riconoscibili - con quella 'continua' - in cui le figure si apprezzano unitariamente -, quindi la sostanziale sparizione ai nostri occhi dei pixel, dipende in buona parte dalle dimensioni di ciascuno di essi, vale a dire da quanto è fitta la loro trama cioè dalla risoluzione dell'immagine.

Un trend apparentemente inarrestabile sembra proporre innovazioni continue che prospettano immagini ad altissima risoluzione. Se si confronta lo schermo grafico di due computer di costo analogo [I] costruiti a distanza di circa quarant'anni, si nota come il più vecchio fosse in grado di gestire meno di 3000 pixel in bianco e nero (64 × 44 punti di risoluzione) mentre il più recente ha una risoluzione di 4096 × 2304 pixel (circa 10 milioni) ciascuno dei quali offre una gamma di milioni di colori. La dimensione del singolo pixel, il cui lato misurava circa un centimetro, ora è inferiore ad un decimo di millimetro, quasi invisibile e ha perso del tutto - anche per motivi legati alla struttura dell'occhio umano [2] - la propria individuale rilevanza all'interno dell'immagine.

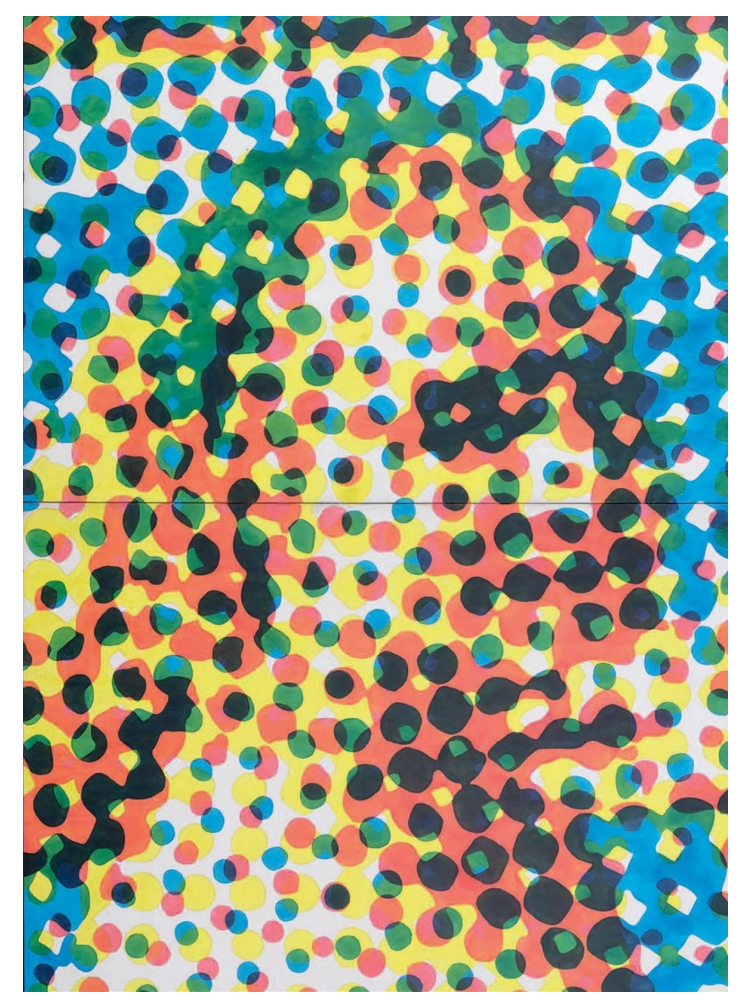


Nonostante il successo di questa sfrenata evoluzione, il nostro modo di fruire le immagini è ben più complesso ed interessante di quanto mostrino gli sforzi univoci compiuti per realizzare (e possedere) schermi a risoluzione sbalorditiva. Un solido portato culturale, ancora oggi ampiamente condiviso, rende le immagini a bassa risoluzione degne di un interesse generale favorendo la loro diffusione capillare soprattutto nel mondo dei giochi e dei videogiochi.

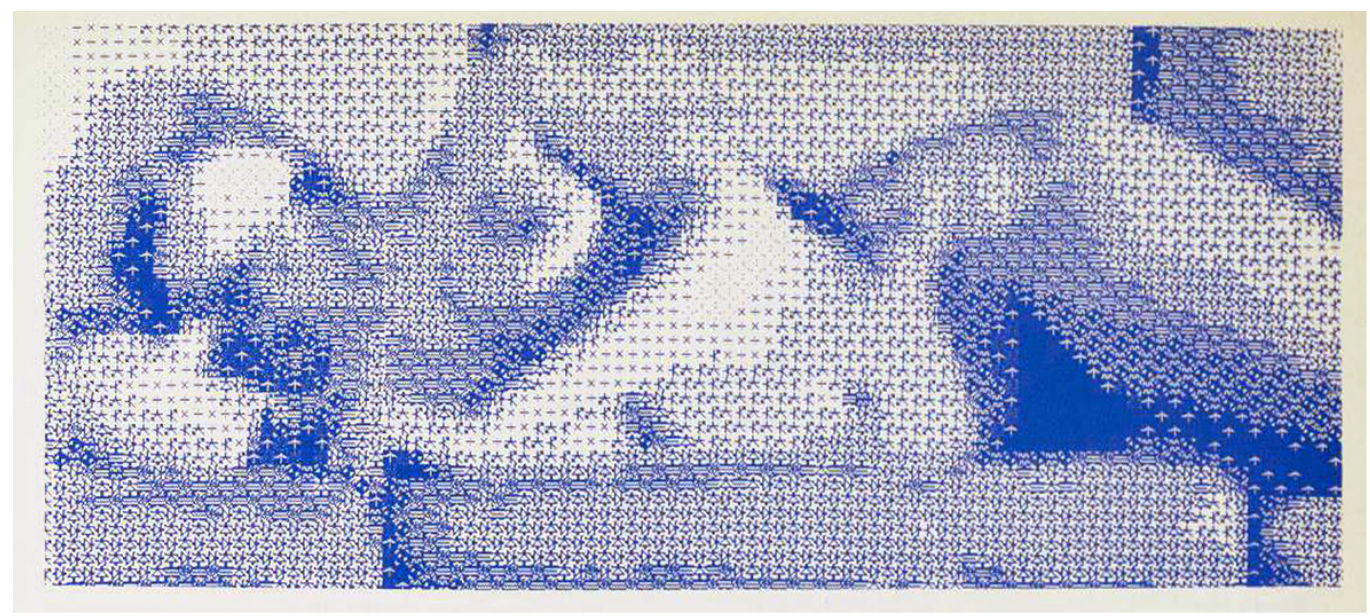

\section{Le arti figurative}

La questione della evoluzione delle immagini digitali è un argomento che coinvolge sia l'ambito della tecnica che quello dell'arte. Anzi, probabilmente è proprio il dibattito nel mondo dell'arte ad ispirare in alcuni passaggi cruciali lo sviluppo di nuove linee di indagine. In questa vicenda, forse più che in ogni altro caso, appare evidente come l'arte - come acutamente nota McLuhan [McLuhan 2008, p. 231; Pinotti, Somaini 20I6, pp. 202, 203] - sia riuscita a fornire una "conoscenza anticipata di come affrontare le conseguenze psichiche e sociali della prossima tecnologia" permettendo di disporre dell' "esatta informazione del modo in cui va predisposta la psiche per prevenire il prossimo colpo delle nostre estese facoltà". II senso dei mutamenti culturali introdotti in questa evoluzione non può essere compreso se non facendo riferimento - brevemente e senza alcuna pretesa di completezza - alla cultura figurativa degli ultimi decenni, prendendo anche in considerazione alcune acquisizioni della seconda metà dell'Ottocento.

Già nel I 852 William FoxTalbot aveva brevettato l'uso di una sorta di retino tipografico per la riproduzione fotomeccanica a stampa delle immagini, i cosiddetti mezzitoni [Stulik, Kaplan 2000], riuscendo sostanzialmente a 'disgregare' l'immagine continua in una tessitura di punti neri, più o meno radi. La diffusione delle scoperte sulla natura del colore di Maxwell e Von Helmholtz e delle leggi di Chevreul [Rood 1979-8I ], rese possibile nel I 878 la messa a punto della tecnica dei cosiddetti benday dots [3] per la riproduzione di immagini a colori, ancora utilizzati nelle moderne riproduzioni a stampa. II principio era quello di ottenere i vari colori e le loro sfumature usando una tessitura di minutissimi cerchi colorati che osservati dalla distanza corretta si fondono tra loro sino a ricomporre l'immagine complessiva. Anche sulla scorta di questi esperimenti, tra il I 884 e il 1887 Georges Seurat dipinse Un dimanche après-midi à l'ille de la Grande Jatte, uno dei quadri più rappresentativi del cosiddetto 'puntinismo'. L'uso di questa ed analoghe tecniche pittoriche si diffuse in modo capillare e artisti impegnati nelle ricerche più diverse - si pensi ad esempio alla Notte stellata di Van Gogh del 1889 - ne fecero largo uso. Agli inizi del Novecento simili esempi si moltiplicarono e agli albori del Futurismo (Rissa in Galleria del 1910 di Umberto Boccioni, Ragazza che corre 
sul balcone del 1912 Giacomo Balla, tra gli altri) si ebbero esempi molto rappresentativi di come l'uso esplicito della bassa risoluzione potesse mutarsi in una piena intensità espressiva. Mentre la tecnica di stampa dei Benday Dots si perfezionava, dai primi anni Sessanta si assistette nel mondo dell'arte allo sviluppo di una riflessione collettiva di grande interesse sul tema dell'immagine e dei suoi elementi costitutivi. Le opere di Roy Lichtenstein Magnifing Glass e Whaam, entrambe del 1963, enfatizzando l'evidenza del retino tipografico impegnano l'osservatore in una riflessione sui limiti di riconoscibilità delle figure. Nel 1965 al MOMA si inaugurò la The Responsive Eye, una mostra collettiva che esplorò i meccanismi con cui il nostro apparato visivo costruisce la percezione delle forme, mettendo spesso in crisi solide certezze. Nello stesso anno per la prima volta venne utilizzata la parola pixel su un articolo tecnico relativo alla tecnologia di riproduzione delle immagini [Lyon 2006]. Presto il termine divenne di dominio pubblico entrando nel vocabolario comune. In questi anni molti artisti fornirono letture personali dei meccanismi della visione enfatizzando singoli elementi puntiformi. A puro titolo di esempio si veda Le dejéuner sur l'herbe di Alain Jacquet del 1964 (fig. I) in cui il retino tipografico è ingrandito centinaia di volte.

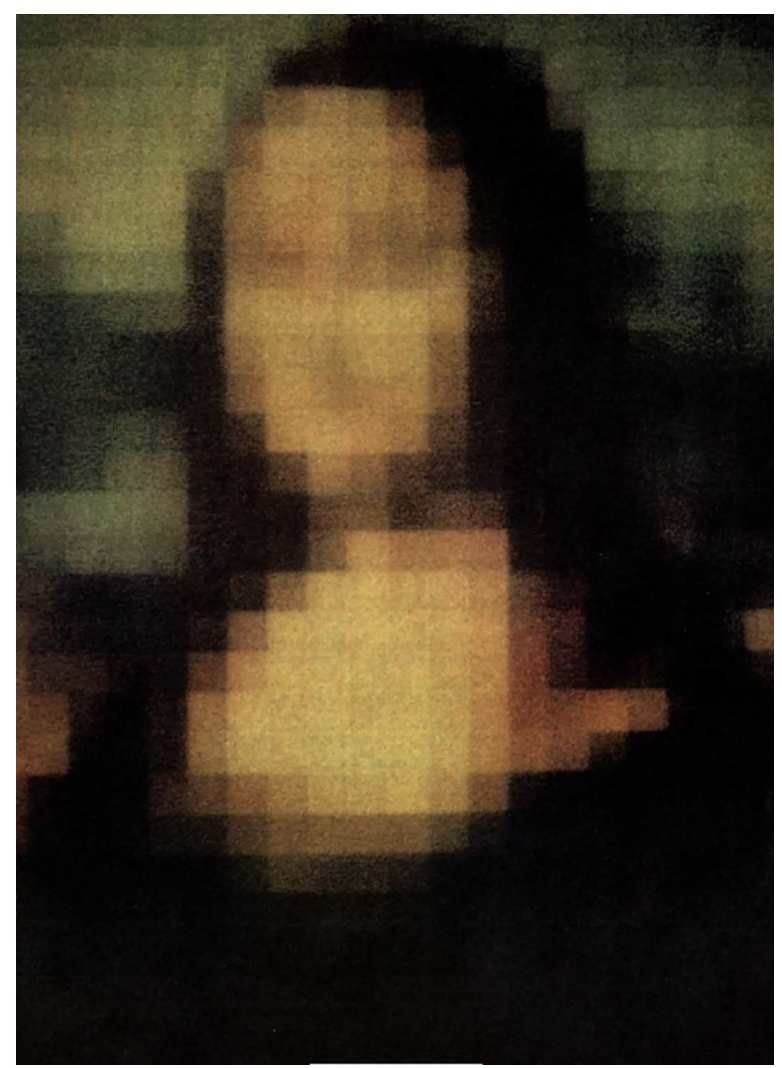

Tra le tendenze della pittura figurativa si andava delineando un filone che nel $1970 \mathrm{Nam}$ June Paik definì con chiarezza: "we are moving in TV from high fidelity pictures to low fidelity. From Giotto to Rembrandt the aim was fidelity to nature. Monet changed all that" [Fineberg 2000, p. 352].

Questo percorso trasse nuova linfa dal mondo della cibernetica e dell'informatica. Attorno al 1967 presso i Bell Telephone Laboratories gli scienziati Leo Harmon e Kenneth Knowlton lavoravano alla trascrizione automatizzata di immagini continue in figure formate da elementi discreti. Sul New York Times pubblicarono il nudo della danzatrice Deborah Hay reso con un'immagine a bassissima definizione (fig. 2). L'anno seguente ne fu esposta una stampa di 


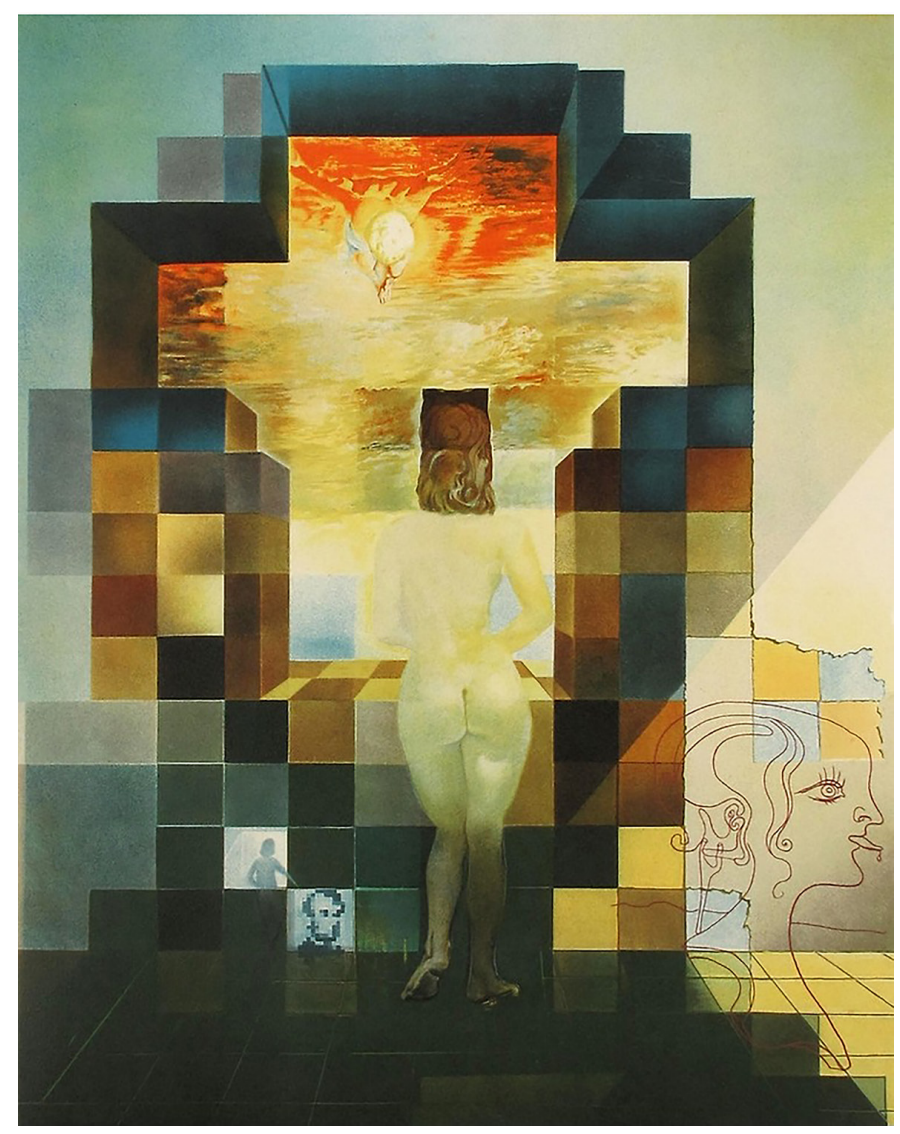

grande formato alla mostra The Machine as Seen at the End of the Mechanical Age tenutasi al MOMA [Hultén 1968, p. 207]. Nel 1973 Harmon pubblicò su Scientific American, The Recognition of Faces, un breve articolo sul tema del riconoscimento facciale illustrato da una serie di immagini ridotte ad una matrice di I 4 × I 8 pixel, tra cui la Gioconda di Leonardo (fig. 3) e l'immagine di Lincoln impressa sulla banconota americana da 5 dollari. Salvator Dalì, in Lincoln in Dalivision del 1976 (fig. 4), utilizzò l'immagine di Harmon ponendola nello sfondo su cui inserì il ritratto della moglie. II dipinto può essere 'letto' a due differenti distanze: da vicino si percepisce l'immagine della donna e da lontano si ricompone l'immagine del volto di Lincoln.

Accanto a questi lavori che giocano sui limiti della riconoscibilità delle immagini nello stesso periodo si sviluppavano esperimenti di grande qualità che esploravano l'ambito di un'estetica non figurativa ispirata dalle matrici quadrate di dots o dai prodotti di memorizzazione informatica - ad esempio le schede perforate - come le straordinarie opere di Jennifer Bartlett realizzate tra il 1972 ed il 1974 (fig. 5) che propongono una sintesi illuminata tra le diverse istanze prese finora in considerazione.

Alla soglia degli anni Ottanta, mentre la computer grafica si affermava definitivamente come mezzo principale di trasmissione ed elaborazione delle immagini, l'esplorazione nell'ambito della relazione tra alta e bassa definizione proseguì con grande vigore. II pittore iperrealista Chuck Close (fig. 6) passò alla costruzione di un linguaggio figurativo raffinatissimo in cui l'immagine è costituita da elementi astratti tra loro giustapposti (fingerprints, dots, losanghe). Negli stessi anni Stan Herd mise a punto una modalità di lavoro che prevede la costruzione di grandi opere realizzate su grandi terreni aperti utilizzando piante, cereali, arbusti, cumuli di terra, materializzando così - per così dire - i pixel in elementi concreti e riconoscibili, producendo immagini che possono essere apprezzate solo dall'alto e da grandi distanze. 

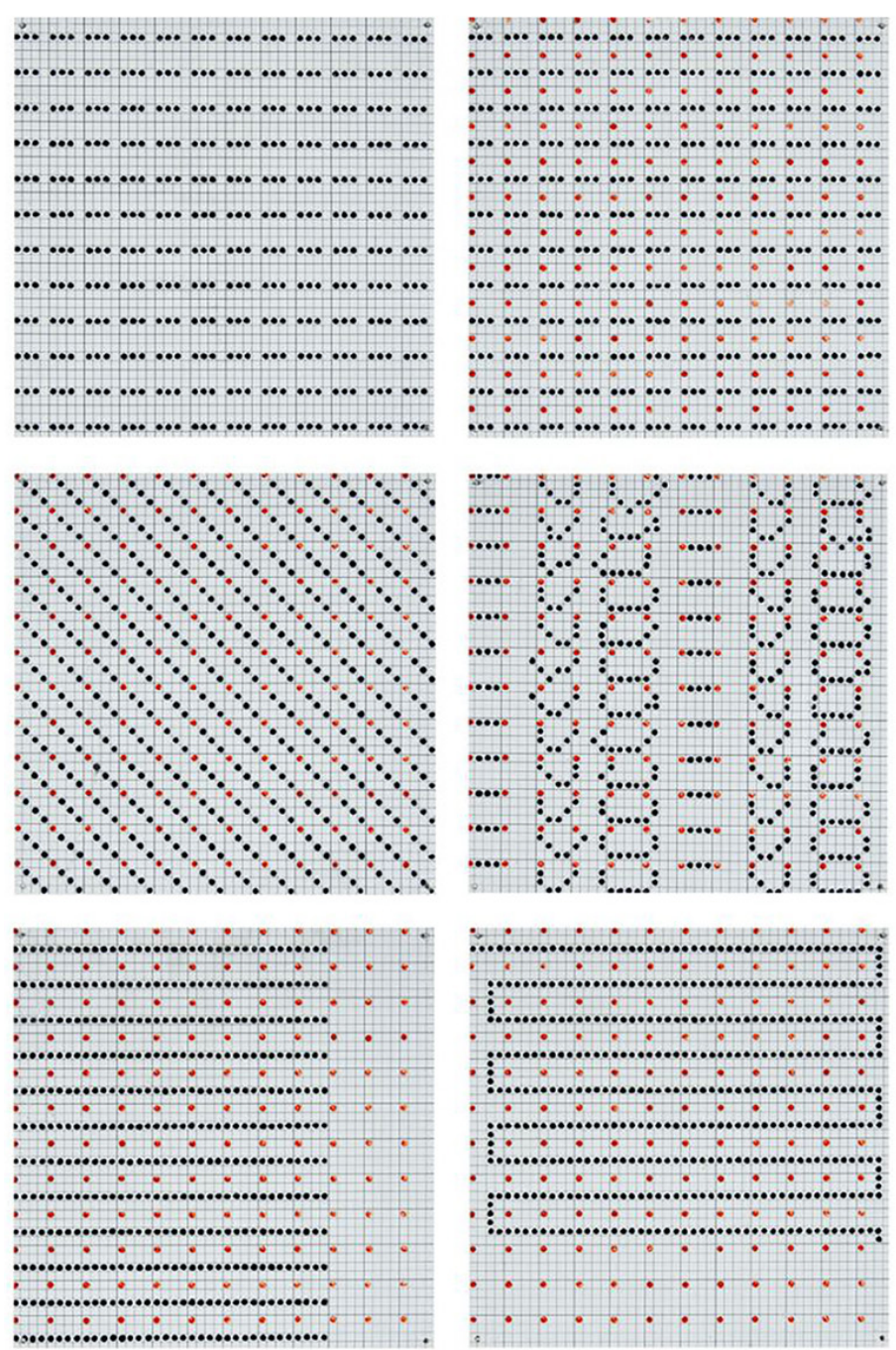

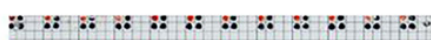

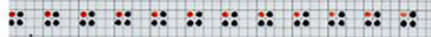

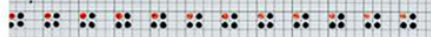

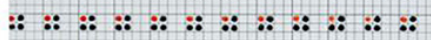

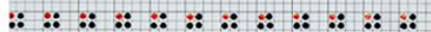

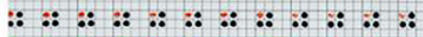
:ः $:$ : $:$ : $:$ : $:$ : $:$ : $:$ : $:$ : $:$ :

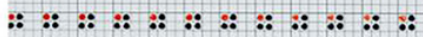

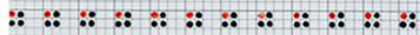

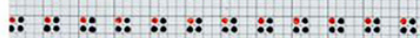

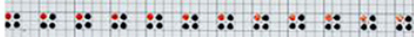

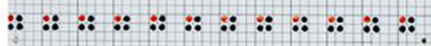
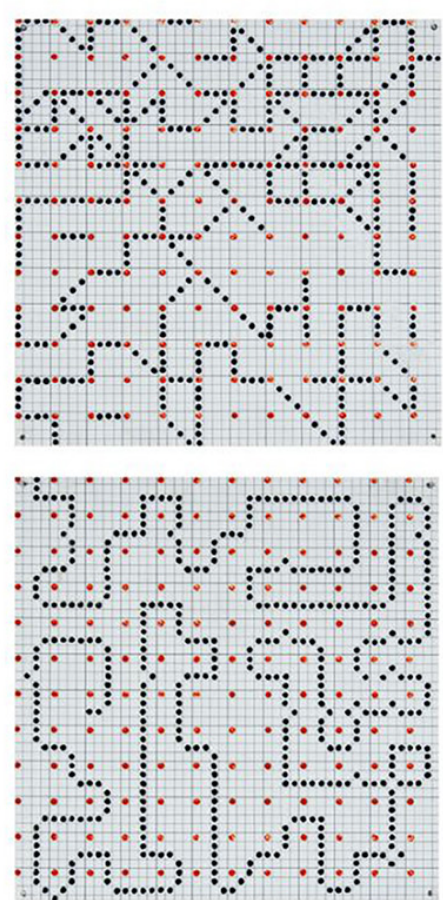

\section{L'ambito del tessile}

II percorso che dalla seconda metà dell'Ottocento sino ai nostri giorni intreccia le acquisizioni nel mondo dell'arte e della scienza su questi temi potrebbe suggerire che la storia della fruizione e della produzione di immagini composte da elementi come i dots o i pixel riguardi solo gli ultimi I 50 anni. A ben vedere invece si tratta di un argomento che affonda la propria origine in tempi lontanissimi e riguarda altri campi della figurazione caratterizzati da immagini a bassa risoluzione.

L'esempio più evidente è certamente legato alla pratica dell'illustrazione musiva la cui origine si perde nella notte dei tempi e la cui storia resta un riferimento ineludibile per capire come ogni evoluzione linguistica non avesse come obbiettivo il superamento della visibilità della singola tessera, (magari riducendone le dimensioni) ma piuttosto come la qualità di ogni opera fosse intrinsecamente legata all'uso consapevole delle potenzialità espressive offerte dal medium.

Ancor più del mosaico, la tradizione della manifattura tessile mostra come immagini e decorazioni geometriche siano state veicolate facendo ricorso ad elementi di immagine - il punto nel ricamo, il nodo nel tappeto, la sovrapposizione dell'ordito alla trama nella tessitura esplicitamente riconoscibili. Molto di rado i tessili vengono accostati per analogia alle trame di pixel. Basta però esaminare alcune delle tavole dell'Encyclopedie dedicate all'argomento 


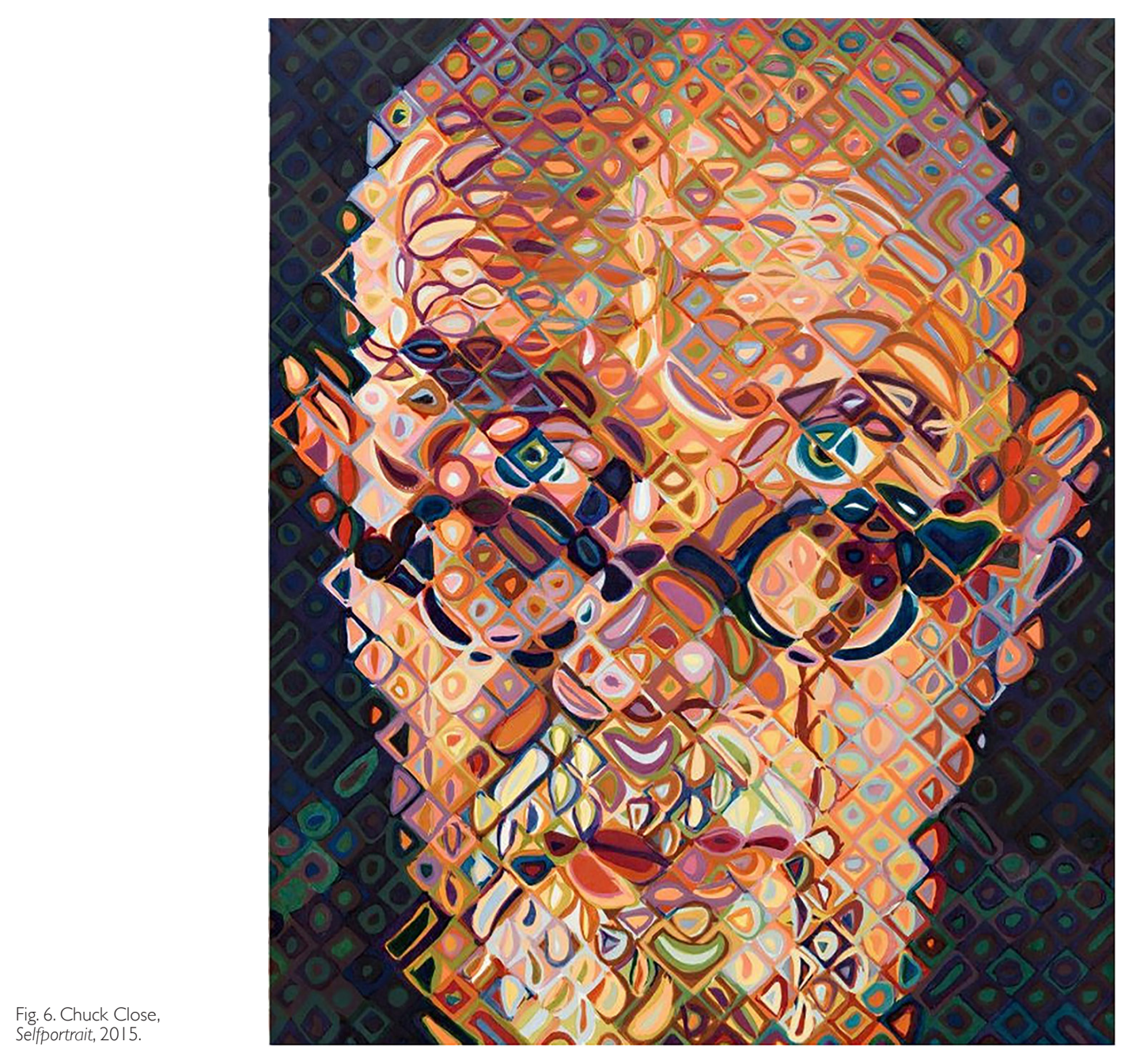

(fig. 7) per capire come ogni traduzione della figura in tessuto necessiti di procedure sostanzialmente identiche a quelle descritte da Harmon per la trascrizione del volto di Lincoln in uno schema 'pixelato'. Allo stesso modo è sufficiente sfogliare, ad esempio, la sorprendente e sterminata produzione di manuali per il cucito ed il ricamo pubblicati alla fine dell'Ottocento - e ancora oggi editi con grande successo - da Therese de Dillmont [Dillmont s.d.], per vedere con quanta sicurezza fosse già allora affrontato il processo di traduzione di disegni continui in matrici composte da singoli elementi quadrati (fig. 8). II nome specifico di questa trascrizione delle immagini è 'messa in carta'. In ogni messa in carta va tracciata una matrice che - come uno schermo digitale - è diviso in pixel quadrati ciascuno dei quali riporta l'informazione elementare, il punto, il nodo o I'alzata' dell'ordito (fig. 9). Quest'operazione costituisce un procedimento che appartiene alla formazione di ciascuna ricamatrice da tempo immemore, ciascuna delle quali, potremmo dire, nella sostanza ha sempre avuto coscienza profonda di cos'è un pixel.

Peraltro un confronto tra alcune tavole dell'Encyclopedie sulla tessitura (fig. I0) e lo schema elettrico di un computer (fig. I I) mostra come tra la logica che sovrintende la realizzazione degli intrecci tessili e la struttura delle macchine informatiche esista un'ulteriore analogia, sorprendente e profonda, che forse solo attraverso il disegno è possibile cogliere con tale nitore. Allo stesso modo, sotto questa luce, gli schemi grafici di Jennifer Bartlett (fig. 5) si pongono perfettamente a cavallo tra l'immagine di una scheda perforata e quella di una messa in carta. 

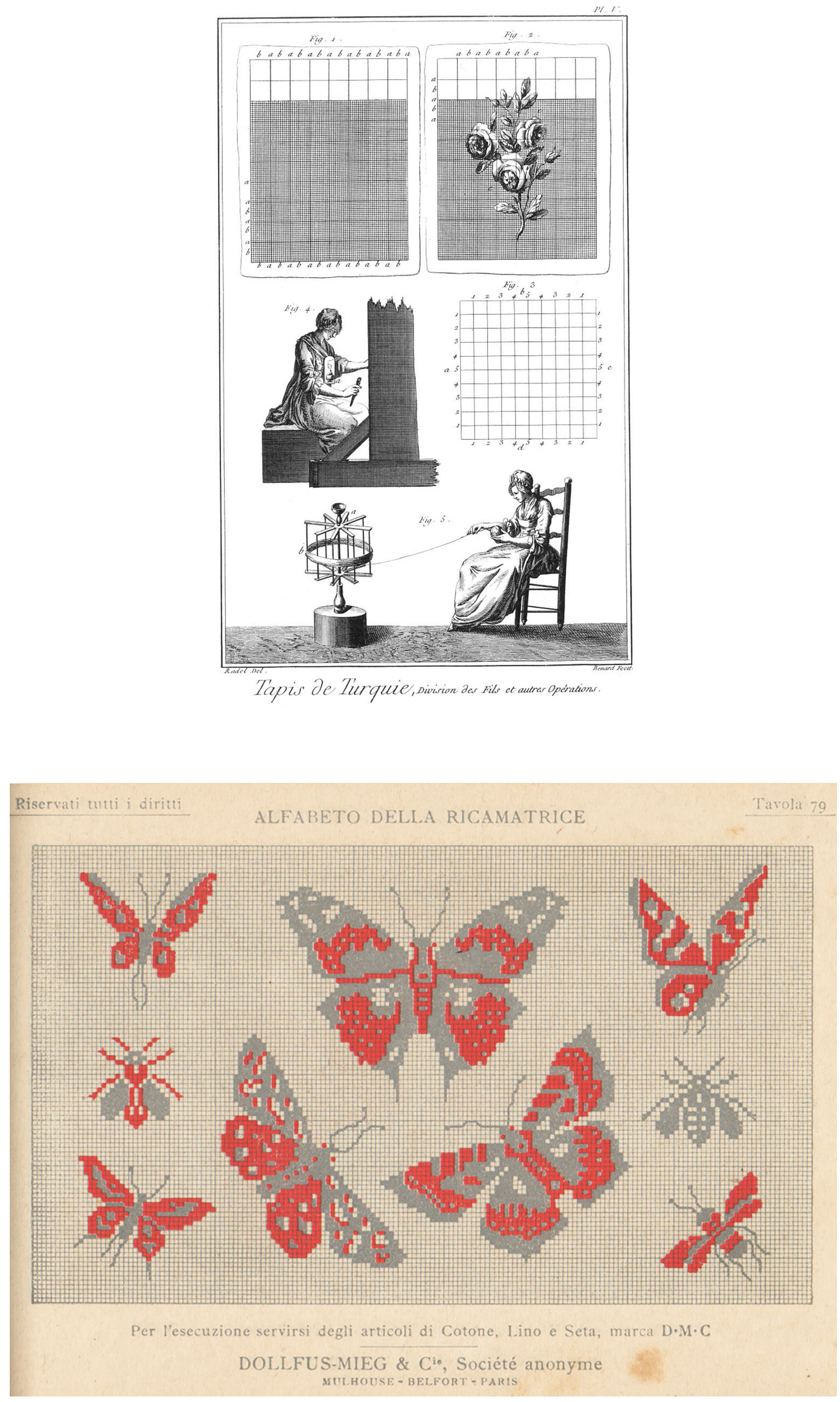
MULHOUSE - BELFORT - PARIS 
Fig. 9. Messa in carta,

Museo didattico della

seta di Como.

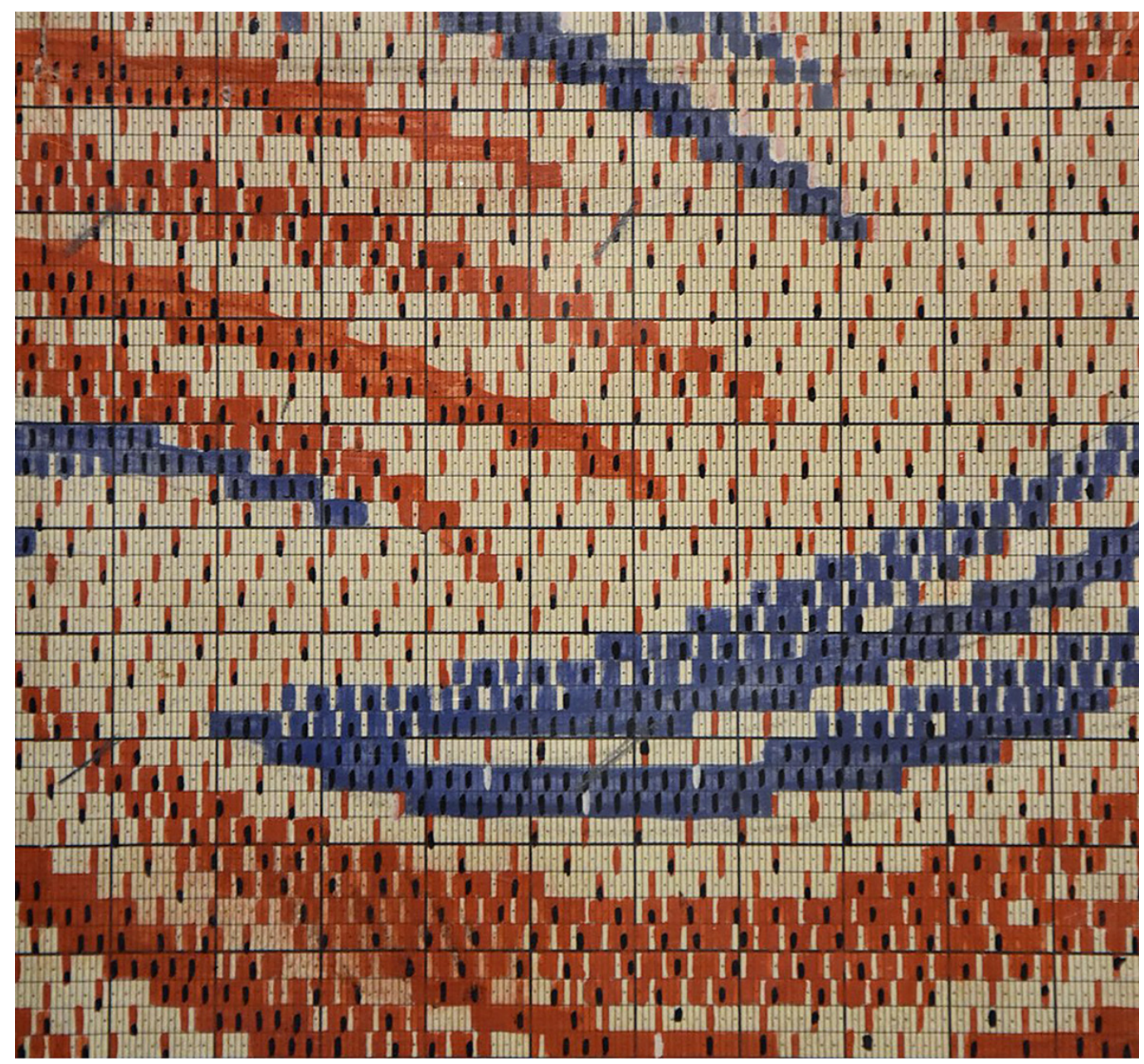



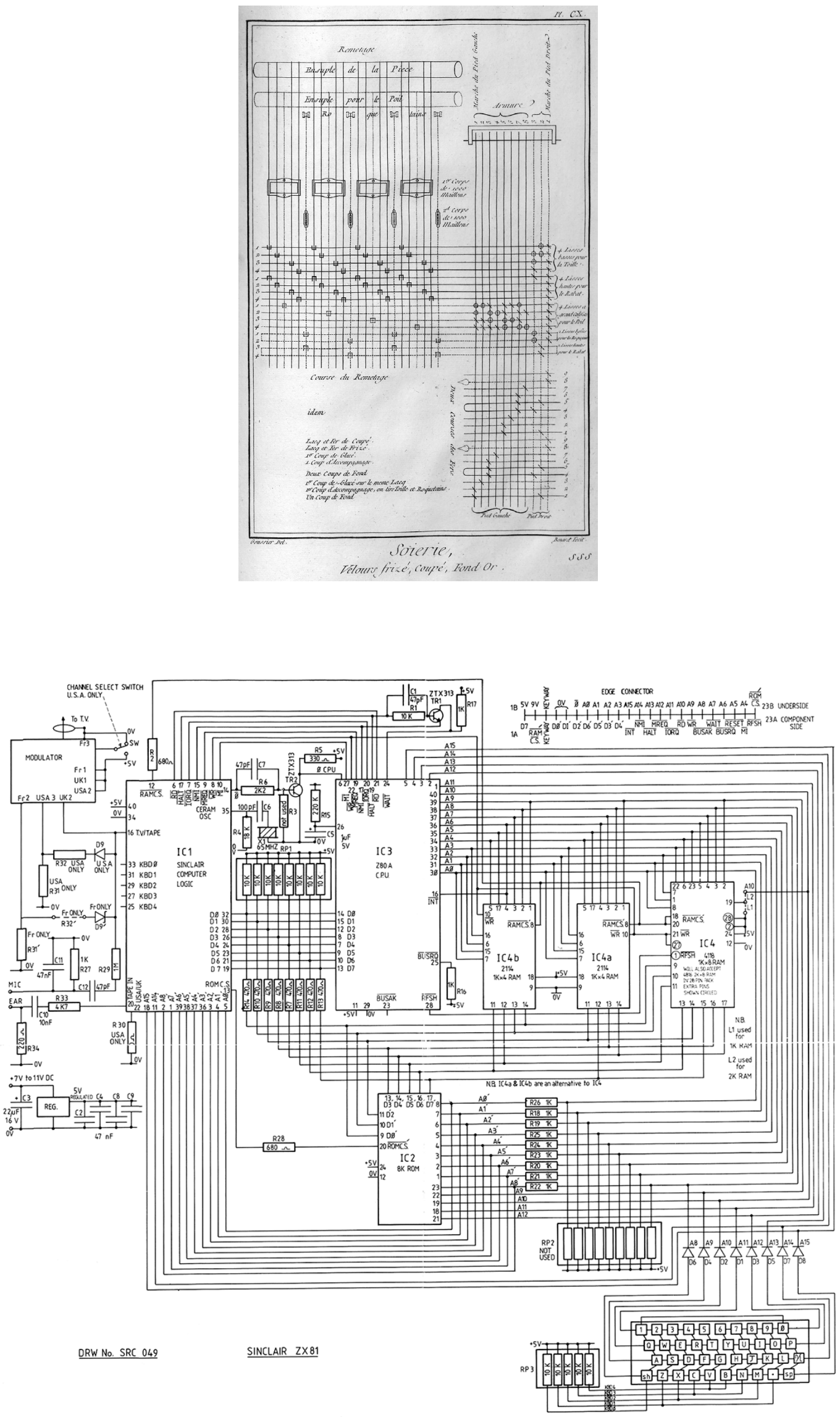


\section{Conclusioni}

Mentre nella cultura visuale degli ultimi secoli si sviluppa un filone che - dalla pittura realista, alla fotografia, alla realtà virtuale - si pone l'obbiettivo della verosimiglianza proponendo di volta in volta dispositivi di supporto all'immagine che mirano all'indistinguibilità dal reale, parallelamente sembra svilupparsi una modalità di visualizzazione low-res che trova nella tradizione del tessile e del mosaico riferimenti visivi solidissimi. Accanto a una evoluzione dei mezzi informatici, che sostanzialmente perseguono l'evanescenza dei pixel, pare diffondersi e radicarsi ulteriormente una tendenza alla fruizione ed alla produzione di immagini a bassa risoluzione che trovano applicazioni privilegiate in campo ludico e videoludico: i 'chiodini colorati' (fig. 12) inventati nel 1945 sono oggi tra i giochi più apprezzati, lkea vende ancora i Pyssla brevettati nel 1962 e alcune applicazioni recenti proposte dalla Lego per i mattoncini tradizionali (Mosaic Maker ad esempio) riscuotono un vivo interesse. II videogioco Minecraft utilizza una grafica a bassissima risoluzione (il volto del protagonista è una matrice di 8x8 pixel) e i tablet supportano comunemente programmi di pixel art per intrattenimento.

La complessità dei meccanismi della percezione visiva giustifica ampiamente questa molteplicità di interessi e di filoni di ricerca. In questo ambito di indagine la Storia della Rappresentazione si rivela un buon alleato per rifuggire dalla tentazione di accogliere con pregiudiziale trionfalismo ogni innovazione tecnica.

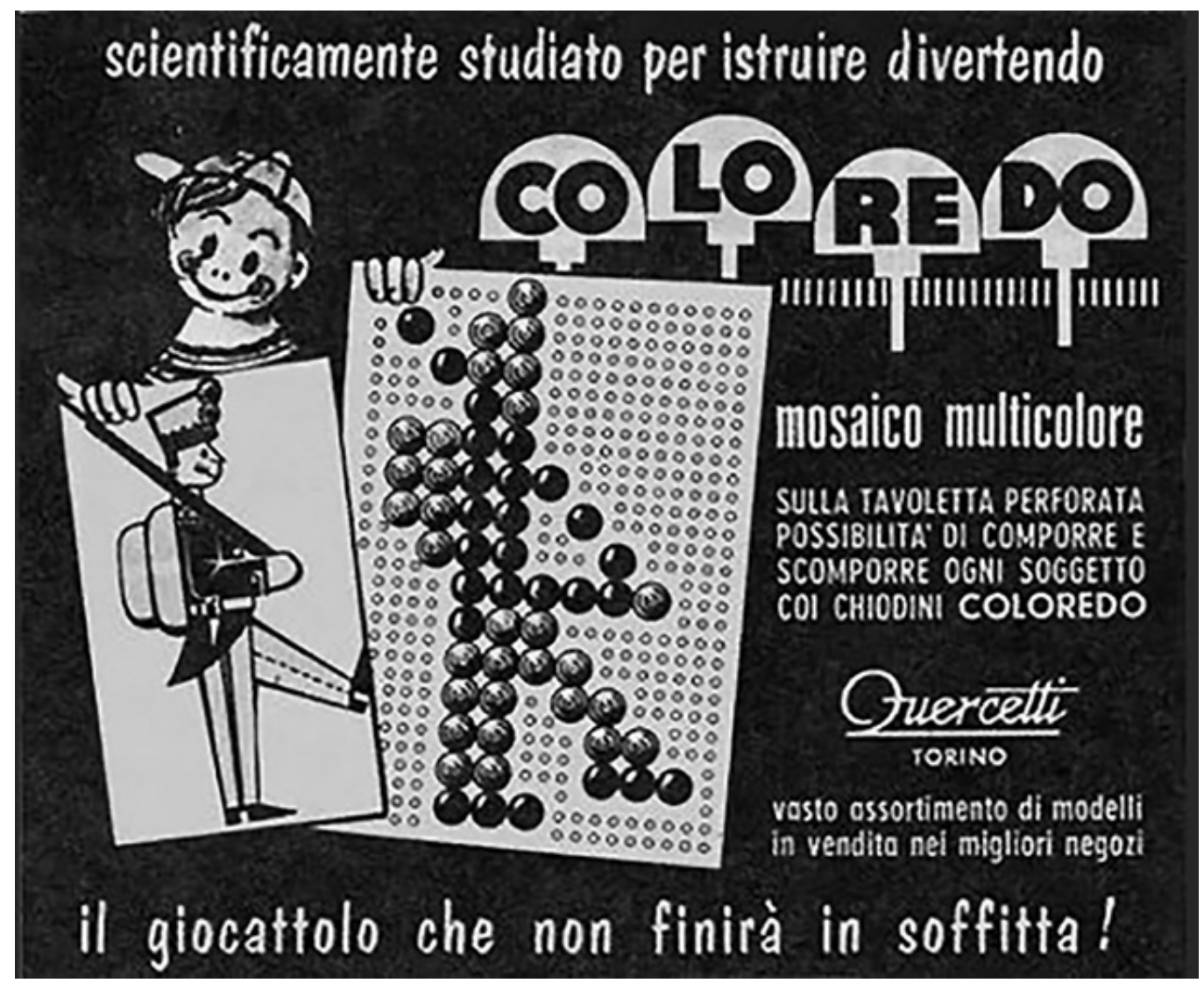

Note

[I] Si confrontano il Sinclair ZX8I del 198I e l'iMac 21,5" retina del 2019, il cui costo attualizzato si aggira sui I000 euro.

[2] II nostro occhio non distingue un oggetto che occupa una dimensione angolare inferiore a $0^{\circ}$, I'. La risoluzione di un televisore con schermo $4 \mathrm{~K}$ da 50" non è apprezzabile ad una distanza superiore agli $80 \mathrm{~cm}$. I pixel di un iPad recente sono invisibili da una distanza superiore ai $25 \mathrm{~cm}$.

[3] L'inventore, Benjamin Day ( 8 | 0- | 889) fu un editore statunitense. 


\section{Riferimenti bibliografici}

De Dillmont Therese (s.d). Alfabeto della Ricamatrice. Lettere, cifre, monogrammi e ornati a punti contati. Mulhouse: Dollfus-Mieg s.d.

Encyclopédie (I75 I-80). Soierie. In Encyclopédie ou Dictionnaire raisonné des sciences, des arts et des métiers. Paris: Le Breton et al.

Fineberg Jonathan (2000). Art Since 1940: Strategies of Being. New York: Harry Abrams Inc.

Gioseffi Decio (1963). Ottica. In Enciclopedia Universale dell'Arte.Venezia-Roma: Ist. per la Collaborazione Culturale.

Harmon Leon (1973). The Recognition of Faces. In Scientific American, vol. 229, n. 5 , pp. 70-83.

Hultén Karl GunnarVougt Pontus (1968). The machine, as seen at the end of the mechanical age. New York: The Museum of Modern Art.

Ings Simon (2008). Storia naturale dell'occhio. Torino: Einaudi. Traduzione di Allegra Panini. (Edizione originale. 2007. The Eye. A natural History. London: Bloomsbury.).

Lyon Richard F. (2006). A Brief History of 'Pixel'. In Proceedings of SPIE - The International Society for Optical Engineering, n. 6069.

Maffioletti Silvio, Ruggeri Letizia (2003). Rilevazione, registrazione e valutazione dell'acutezza visiva. Dispensa del Corso di Laurea in Ottica e Optometria Università degli Studi di Milano Bicocca.

McLuhan Marshall (2008). Gli strumenti del comunicare. Milano: il Saggiatore. (Ed orig. 1964. Understanding Media:The Extensions of Man. New York: Mc Graw Hill).

Pinotti Andrea, Somaini Antonio (20 16). Cultura visuale. Immagini sguardi media dispositivi. Torino: Einaudi, pp. $193-220$.

Rood, Odgen Nicholas ( 1879). Modern Chromatics with Application to Art and Industry. New York: Appleton and Company.

Stulik Dusan C. Kaplan Art (2000). The Halftone. Los Angeles: The Getty Conservation Institute.

Unali Maurizio. (200 I). Pixel di architettura. Roma: Kappa.

Autore

Edoardo Dotto, Università degli Studi di Catania, edoardodotto@hotmail.com

Per citare questo capitolo: Dotto Edoardo (2020). Tessere. Gli elementi costitutivi dell'immagine digitale tra arte, scienza e artigianato/Weaving. The building blocks of the digital image between art, science and craftsmanship. In Arena A., Arena M., Brandolino R.G., Colistra D., Ginex G., Mediati D., Nucifora S., Raffa P. (a cura di). Connettere. Un disegno per annodare e tessere. Atti del $42^{\circ}$ Convegno Internazionale dei Docenti delle Discipline della Rappresentazione/Connecting. Drawing for weaving relationships. Proceedings of the 42th International Conference of Representation Disciplines Teachers. Milano: FrancoAngeli, pp. 3269-3292. 


\title{
Weaving. The Building Blocks of the Digital Image between Art, Science and Craftsmanship
}

\author{
Edoardo Dotto
}

Abstract

Where the evolution in the field of image technology makes monitors, screens and touch-screens available with ever greater resolution - in which the size of each pixel seems to decrease to the threshold of effective visibility - contemporary visual culture, especially in the field of the production of toys and video games, it still retains a strong interest in low resolution types of representation in which the recognizability of the single 'picture element' is the foundation of each aesthetic figure.

The history of the formation of digital images - whose origins benefit from late nineteenth-century acquisitions in the field of optics and painting - unfolds between the sixties and nineties of the last century through continuous references and contaminations between the figurative arts and the most advanced research in the field of computer science. These recently conceived images, organized on dense arrays of square elements, on closer inspection find themselves intertwined in the ancient artisan traditions of mosaic but even more of the different textile technologies which show a very close conceptual analogy with the computer techniques of image support.

A reflection that uses drawing as a tool to grasp the analogies between these images of a different nature can make it clear how the most modern 'low-res media' show a direct connection with visual structures developed through manufacturing practice.

Keywords

pixels, weaving, mosaic, digital images.
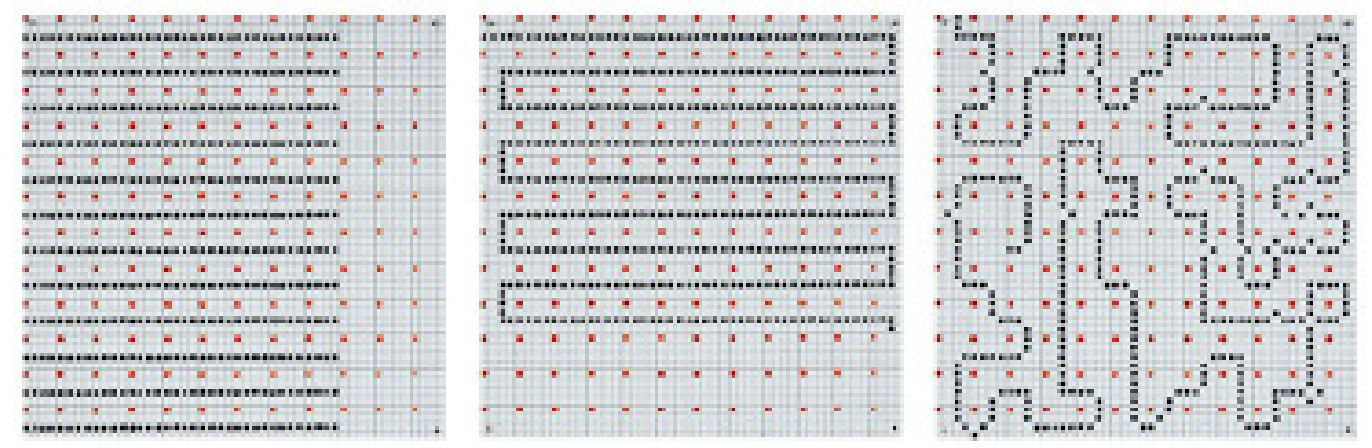


\section{Introduction}

The general theme of 'weaving' and 'connecting' referring to the sphere of drawing and more generally- representation, is revealed as a propitious occasion to tackle a theme that concerns the very structure of digital images. As is known, the substance that forms the backbone of a digital image consists of a dense matrix of square elements, the 'picture elements' or pixels, each of which carries elementary information on the portion of the image it occupies. In its minimum configuration, each pixel can be turned on or off, and constitute the partial element of a black and white image, in which each nuance must be rendered with a skilful mixture of dark or bright squares. In general, each pixel is characterized by a more complex degree of information and can return a color or a gray gradient. The combination of multiple pixels, especially if viewed from an appropriate distance, allows you to appreciate an image in its completeness, so that the weaving of individual discrete elements is neglected to the benefit of the perception of a continuous figure in which the matrix of square elements loses all relevance.

Obviously, the substitution at a perceptual level of the 'discrete' image -made up of separate and recognizable elements- with the 'continuous' one -in which the figures appreciate each other unitically- therefore the substantial disappearance of pixels in our eyes, depends on a good part of the size of each of them, that is to say how dense their texture is, that is the resolution of the image.

A seemingly unstoppable trend seems to offer continuous innovations that propose very high resolution images. If you compare the graphic screen of two computers of similar cost built at a distance of about forty years [ I ], you can see how the older one was able to handle less than 3000 black and white pixels ( $64 \times 44$ resolution points) while the most recent has a resolution of $4096 \times 2304$ pixels (about 10 million) each of which offers a range of millions of colors. The size of the single pixel, whose side measured about one centimeter, is now less than a tenth of a millimeter, almost invisible and has completely lost -also for reasons related to the structure of the human eye [2]- its own individual relevance within the image.

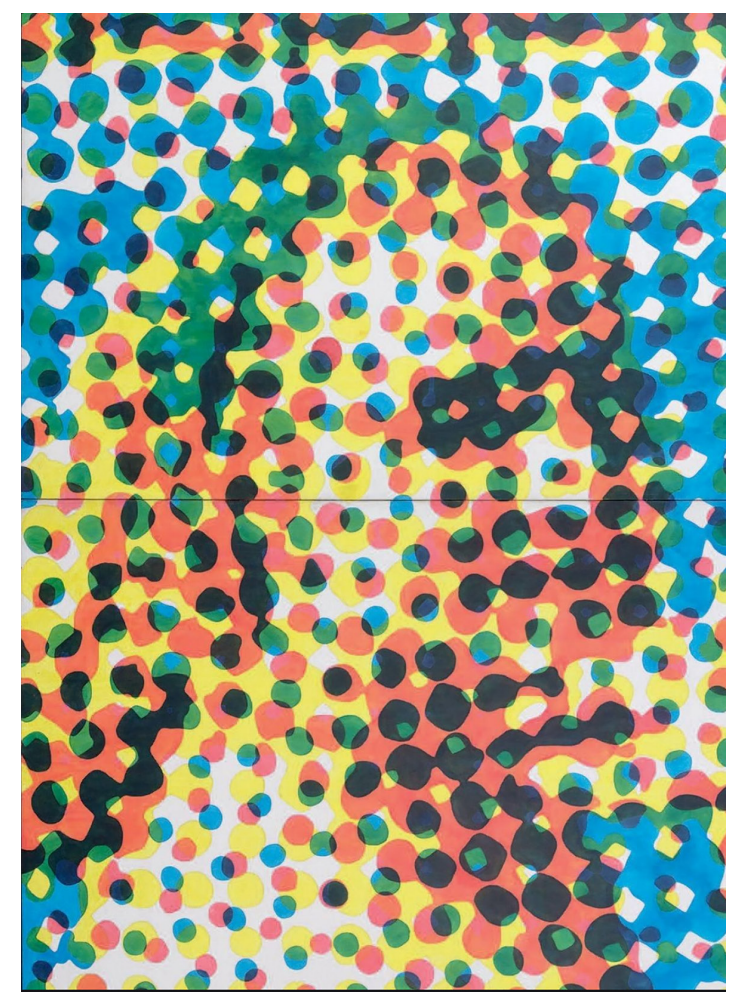


Despite the success of this unbridled evolution, our way of enjoying images is far more complex and interesting than the unequivocal efforts made to create (and own) stunning resolution screens show. A solid cultural background, still widely shared today, makes low resolution images worthy of a general interest, favoring their widespread diffusion, especially in the world of games and videogames.

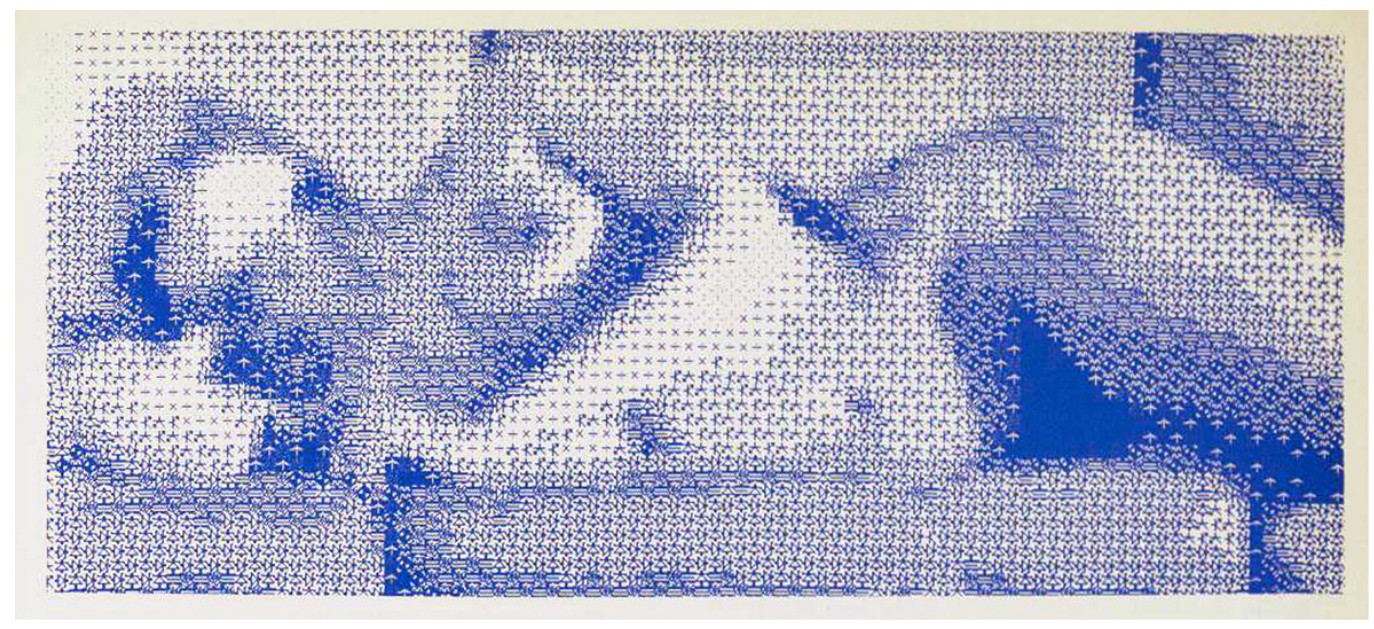

\section{The figurative arts}

The issue of the evolution of digital images is a topic that involves both the field of technology and that of art. Indeed, it is probably the debate in the world of art that in some crucial passages inspires the development of new lines of investigation. In this affair, perhaps more than in any other case, it is evident that art -as McLuhan keenly notes [McLuhan 2008, p. 23I; Pinotti, Somaini 2016, pp. 202-203] -has managed to provide "anticipated knowledge of how to deal with the psychic and social consequences of the next technology" allowing to dispose of the "exact information on the way in which the psyche must be prepared to prevent the next blow of our extensive faculties". The sense of the cultural changes introduced in this evolution cannot be understood except by referring -briefly and without any claim to completeness- to the figurative culture of the last decades, also taking into consideration some acquisitions of the second half of the nineteenth century.

As early as I 852 William Fox Talbot had patented the use of a sort of typographic screen for the photomechanical reproduction of the images, the so-called halftones [Stulik, Kaplan 2000], managing to substantially 'break up' the continuous image into a texture of black dots, more or less sparse. The spread of the discoveries on the nature of color by Maxwell and Von Helmholtz and the laws of Chevreul [Rood 1979-8I], made it possible in 1878 to develop the technique of the so-called Benday Dots [3] for the reproduction of color images, still used in modern printed reproductions. The principle was to obtain the various colors and their shades using a texture of minute colored circles which, observed from the correct distance, blend together to recompose the overall image. Also on the basis of these experiments, between I 884 and I 887 Georges Seurat painted Un dimanche après-midi à l'ille de la Grande Jatte, one of the most representative paintings of the so-called 'pointillism'. The use of this and similar pictorial techniques spread widely and artists engaged in the most diverse research -think for example of the Starry Night by Van Gogh of I 889- made extensive use of it. At the beginning of the twentieth century similar examples multiplied and at the dawn of Futurism (Rissa in Galleria del 1910 by Umberto Boccioni, Ragazza che corre sul balcone of 1912 by Giacomo Balla, among others) there were very representative examples of how the explicit use of the low resolution could change into a full expressive intensity. 
While the Benday Dots printing technique was perfected, from the early sixties there was the development of a collective reflection of great interest in the art world on the theme of the image and its constituent elements. The works of Roy Lichtenstein Magnifing Glass and Whaam, both from 1963, emphasizing the evidence of the typographic screen, engage the observer in a reflection on the limits of recognisability of the figures. In 1965, The Responsive Eye was inaugurated at MOMA, a collective exhibition that explored the mechanisms by which our visual apparatus constructs the perception of forms, often putting solid certainties into crisis. In the same year, the word pixel was used for the first time on a technical article relating to image reproduction technology [Lyon 2006]. Soon the term became public knowledge and entered the common vocabulary. In these years many artists provided personal readings of the mechanisms of vision emphasizing single point elements. By way of example, see Alain Jacquet's Le dejéuner sur l'herbe from 1964 (fig. I) in which the typographic screen is enlarged hundreds of times.

Among the trends of figurative painting, a trend was emerging that in June Nam June Paik clearly defined: "we are moving on TV from high fidelity pictures to low fidelity. From Giotto to Rembrandt the aim was fidelity to nature. Monet changed all that" [Fineberg 2000, p. 352].

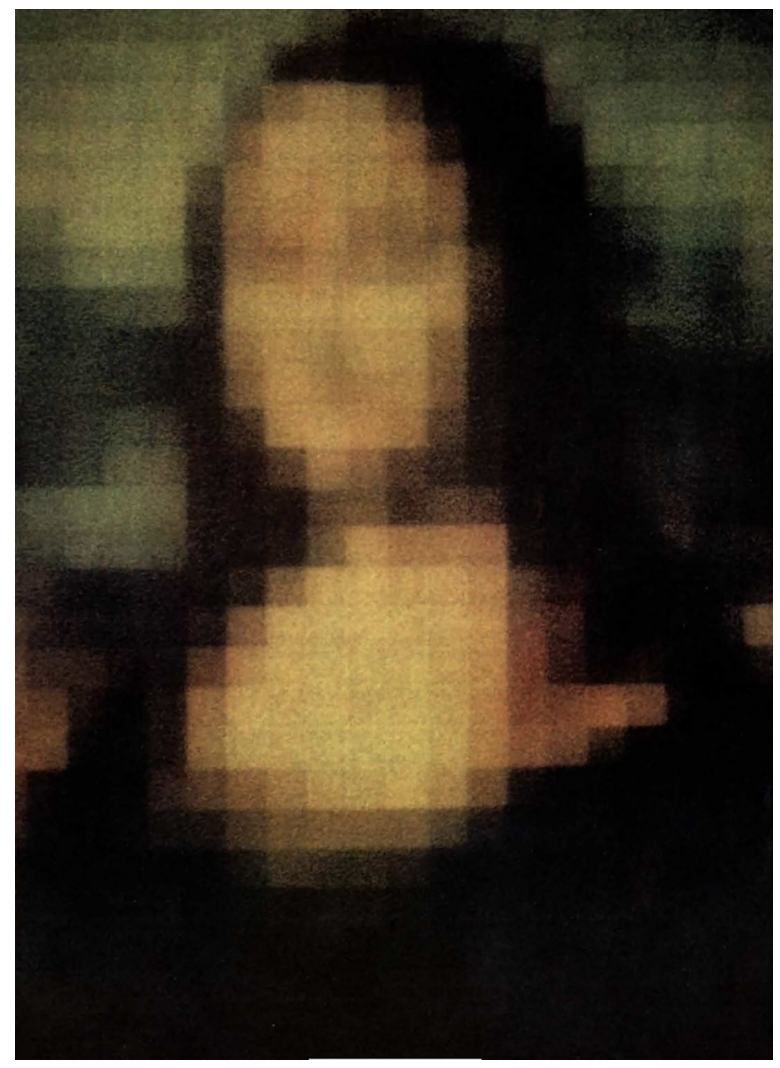

This path drew new lymph from the world of cybernetics and information technology. Around 1967 at Bell Telephone Laboratories the scientists Leo Harmon and Kenneth Knowlton worked on the automated transcription of continuous images into figures formed by discrete elements. In the New YorkTimes they published the nude of the dancer Deborah Hay rendered with a very low definition image (fig. 2). The following year, a large format print was exhibited at the exhibition The Machine as Seen at the End of the Mechanical Age held at MOMA [Hultén 1968, p. 207]. In 1973 Harmon published in Scientific American The Recognition of Faces, a short article on the theme of facial recognition illustrated by a series of images reduced to a matrix of I 4 × 18 pixels, including Leonardo's Mona Lisa (fig. 3) 


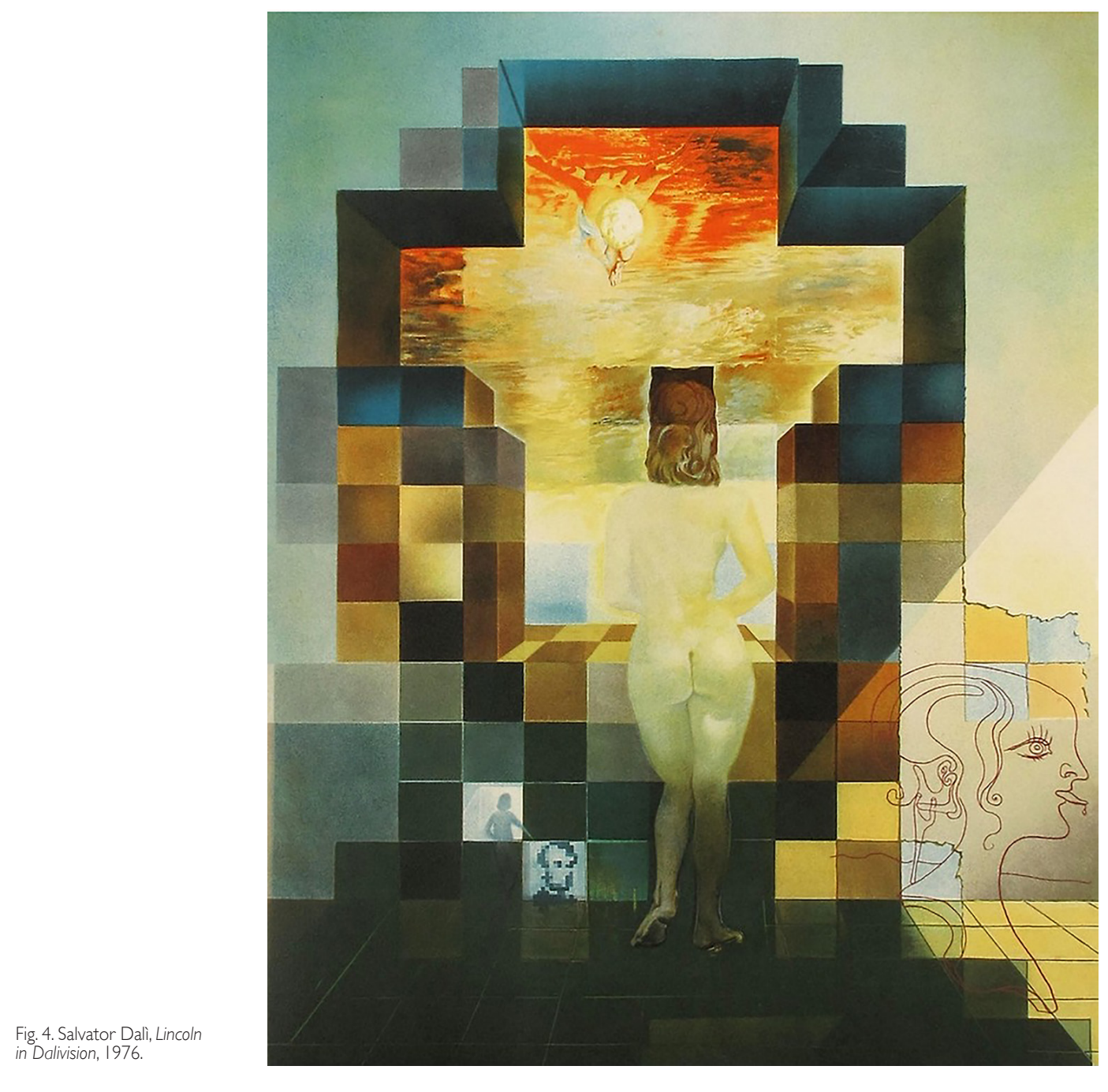

and the image of Lincoln imprinted on the American 5 dollar bill. Salvator Dalì, in Lincoln in Dalivision of 1976 (fig. 4), used the image of Harmon placing it in the background on which he inserted the portrait of his wife. The painting can be 'read' at two different distances: the image of the woman is perceived up close and the image of Lincoln's face is recomposed from a distance.

Alongside these works that play on the limits of recognisability of images in the same period, high-quality experiments were developed that explored the sphere of a non-figurative aesthetic inspired by the square matrices of dots or by computer storage products -for example punched cards- like the extraordinary works by Jennifer Bartlett created between 1972 and 1974 (fig. 5) which offer an enlightened synthesis between the various instances taken into consideration so far.

At the threshold of the 1980s, while computer graphics were definitively established as the main means of transmission and image processing, exploration of the relationship between high and low definition continued with great vigor.The hyper-realistic painter Chuck Close (fig. 6) went on to construct a very refined figurative language in which the image is made up of abstract elements juxtaposed to each other (fingerprints, dots, lozenges). In the same years Stan Herd developed a way of working that involves the construction of large works built on large open land using plants, cereals, shrubs, heaps of earth, thus materializing -so to speak - the pixels in concrete and recognizable elements, producing images that can be appreciated only from above and from great distances. 

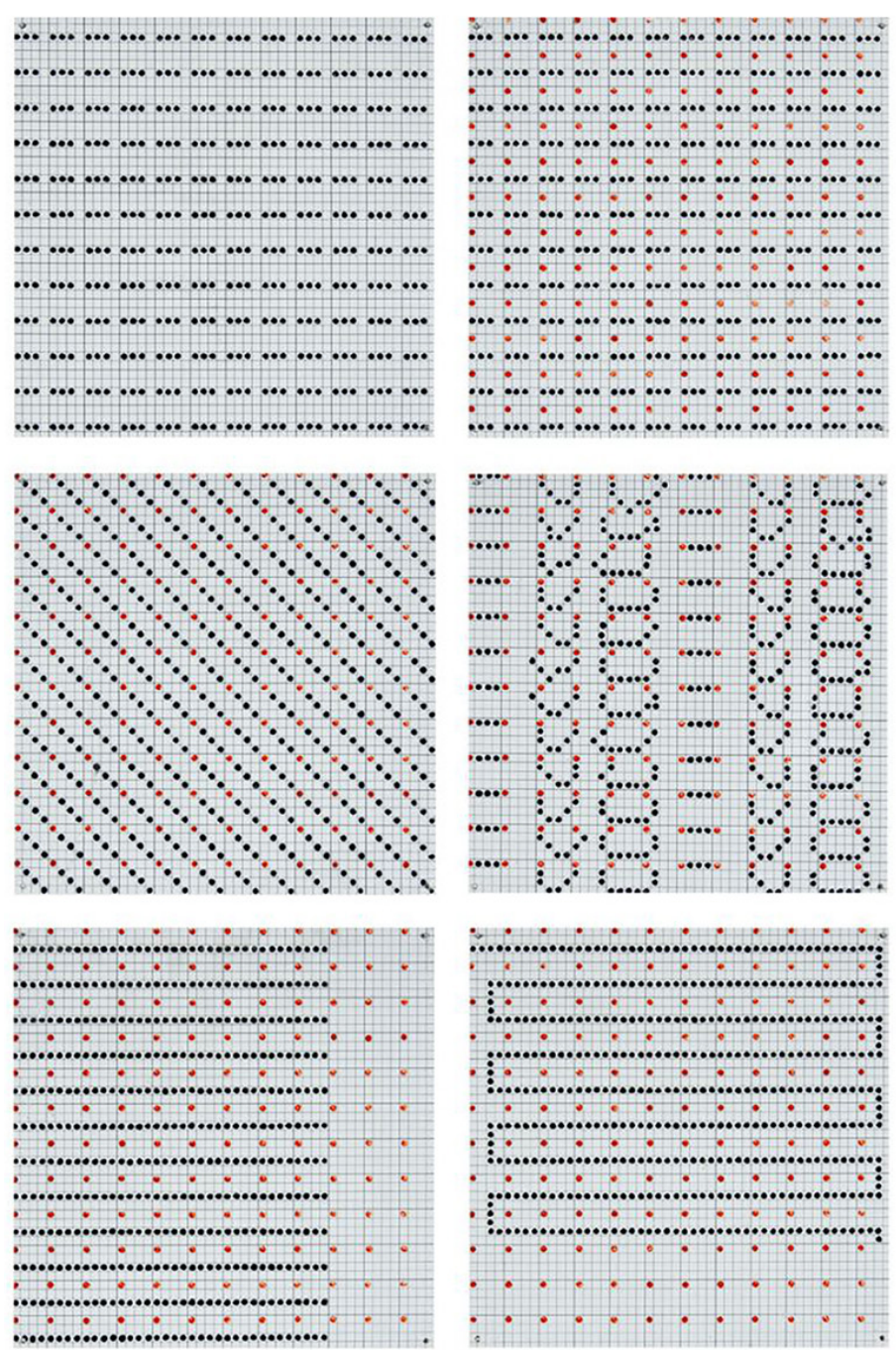

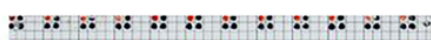

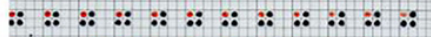

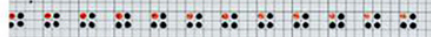

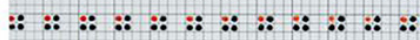

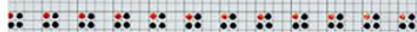

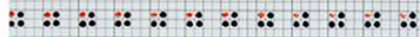

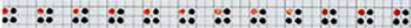

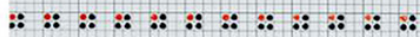

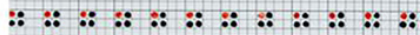

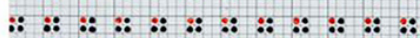

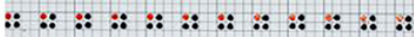

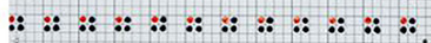
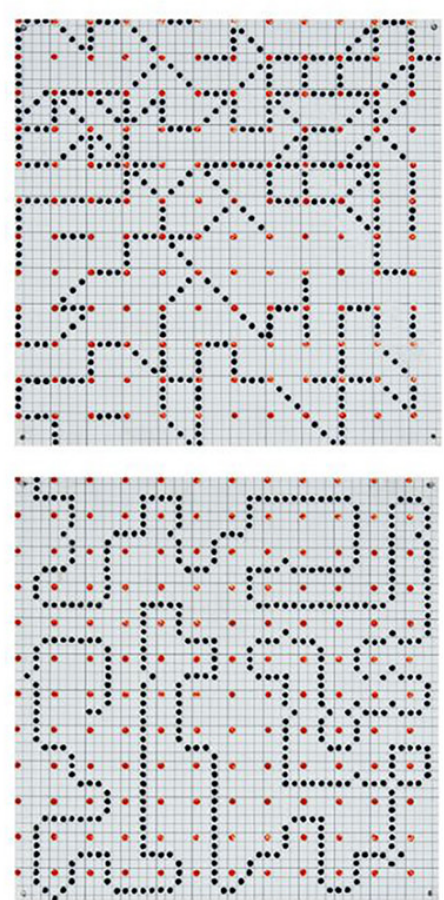

\section{The field of textiles}

The path that from the second half of the nineteenth century to the present day intertwines acquisitions in the world of art and science on these themes could suggest that the history of the fruition and production of images composed of elements such as dots or pixels concerns only the past 150 years. On closer inspection, however, it is a topic that has its origins in very distant times and concerns other fields of figuration characterized by low-resolution images.

The most evident example is certainly linked to the practice of mosaic illustration whose origin is lost in the mists of time and whose history remains an unavoidable reference to understand how every linguistic evolution did not have as objective the overcoming of the visibility of the single card, (perhaps reducing its dimensions) but rather how the quality of each work was intrinsically linked to the conscious use of the expressive potential offered by the medium.

Even more than mosaic, the tradition of textile manufacturing shows how images and geometric decorations have been conveyed by resorting to image elements -the stitch in the embroidery, the knot in the carpet, the superposition of the warp to the weave in the weaving- explicitly recognizable. Very rarely, textiles are brought together by analogy to pixel textures. However, it is sufficient to examine some of the Encyclopedie tables dedicated 


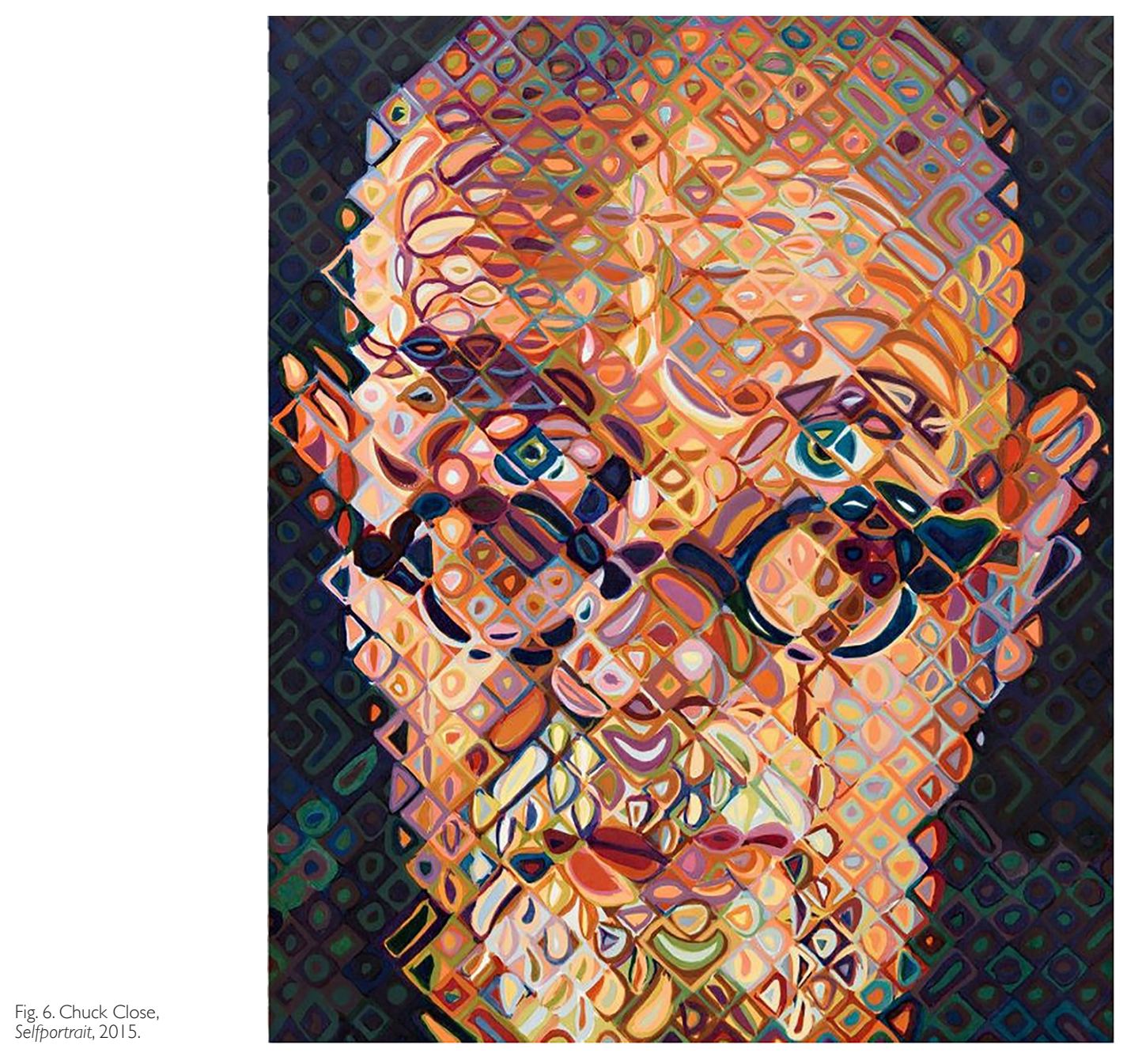

to the subject (fig. 7) to understand how each translation of the figure in fabric requires procedures substantially identical to those described by Harmon for the transcription of Lincoln's face in a 'pixelated' scheme. In the same way it is sufficient to browse, for example, the surprising and endless production of manuals for sewing and embroidery published at the end of the nineteenth century -and still edited with great success- by Therese de DilImont [Dillmont s.d.], to see how confident it was already then he dealt with the process of translating continuous drawings into matrices composed of single square elements (fig. 8). The specific name of this transcription of the images is "put on paper". In each paper placement, a matrix is traced which -like a digital screen- is divided into square 'pixels', each of which reports the basic information, the point, the node or the 'elevation' of the warp (fig. 9). This operation constitutes a procedure that belongs to the training of each embroiderer from time immemorial, each of whom, we could say, in substance has always had a profound awareness of what a pixel is.

Moreover, a comparison between some tables of the Encyclopedie on the weaving (fig. 10) and the wiring diagram of a computer (fig. II) shows how between the logic that oversees the creation of textile weaves and the structure of computer machines there is a further an analogy, surprising and profound, that perhaps only through the drawing it is possible to grasp with such a sharpness. In the same way, in this light, the graphic schemes of Jennifer Bartlett (fig. 5) are perfectly positioned between the image of a punched card and that of a paper placement. 

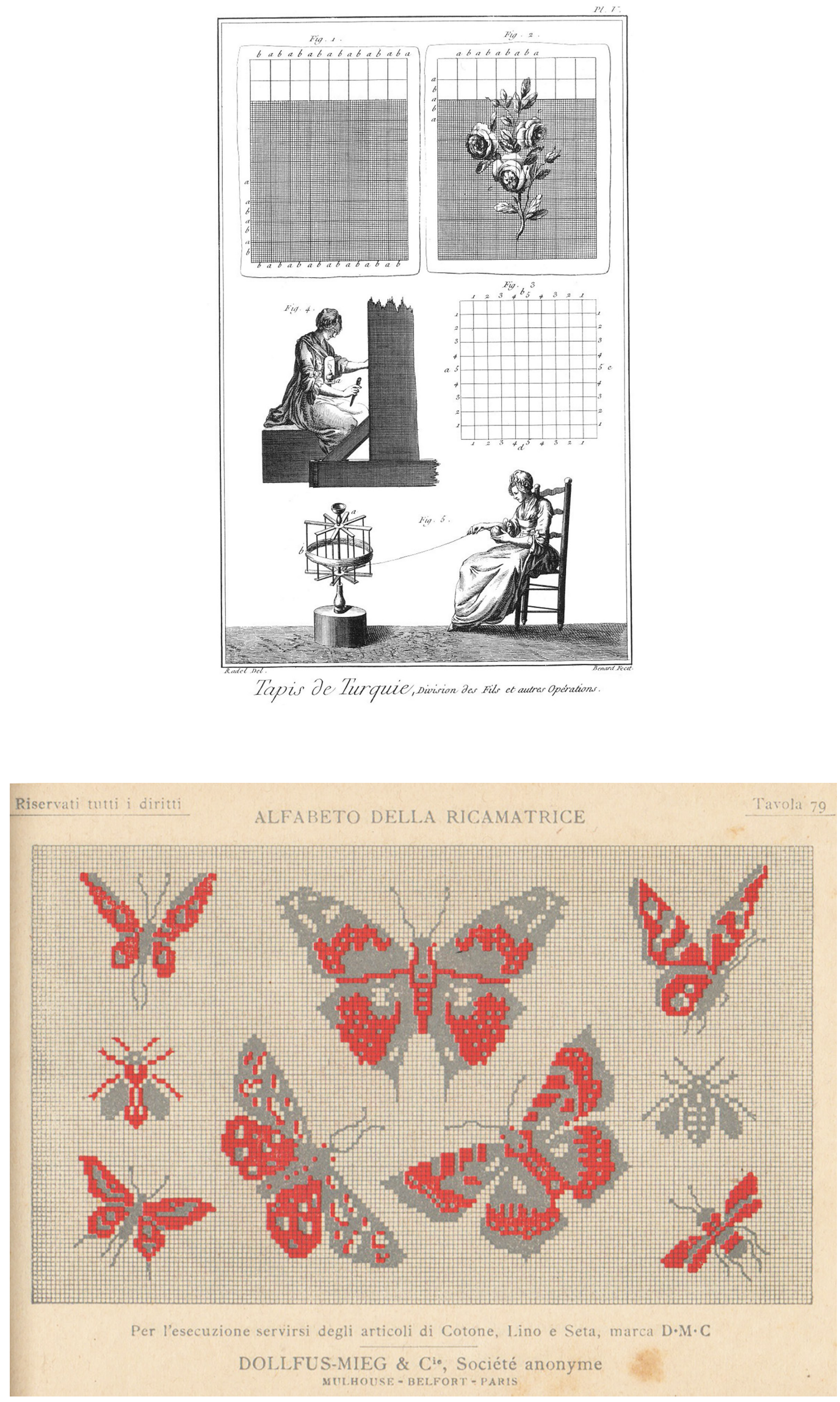
MULHOUSE - BELFORT - PARIS 
Fig. 9. Put on paper, Mu-

seo didattico della seta

di Como.

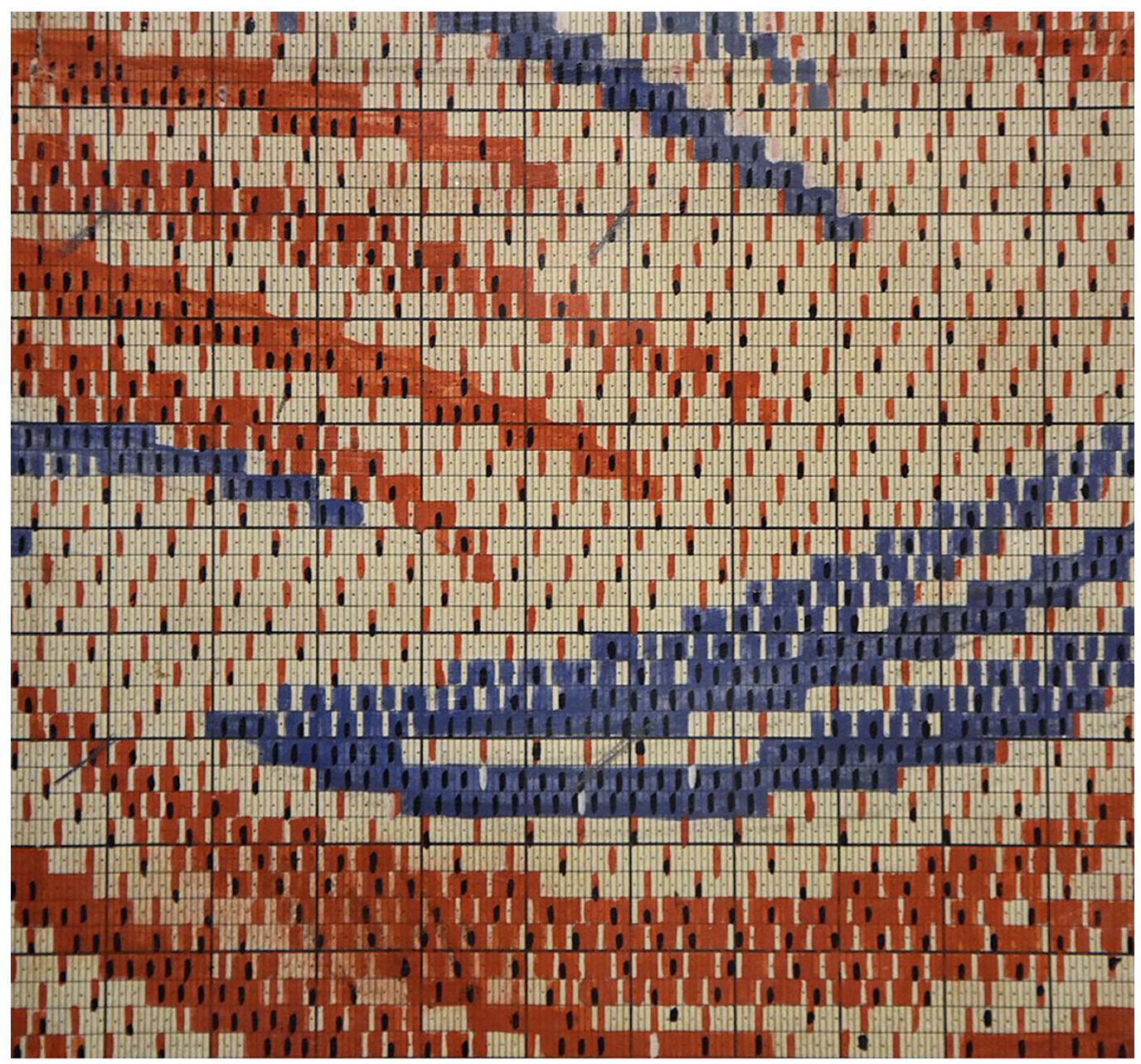



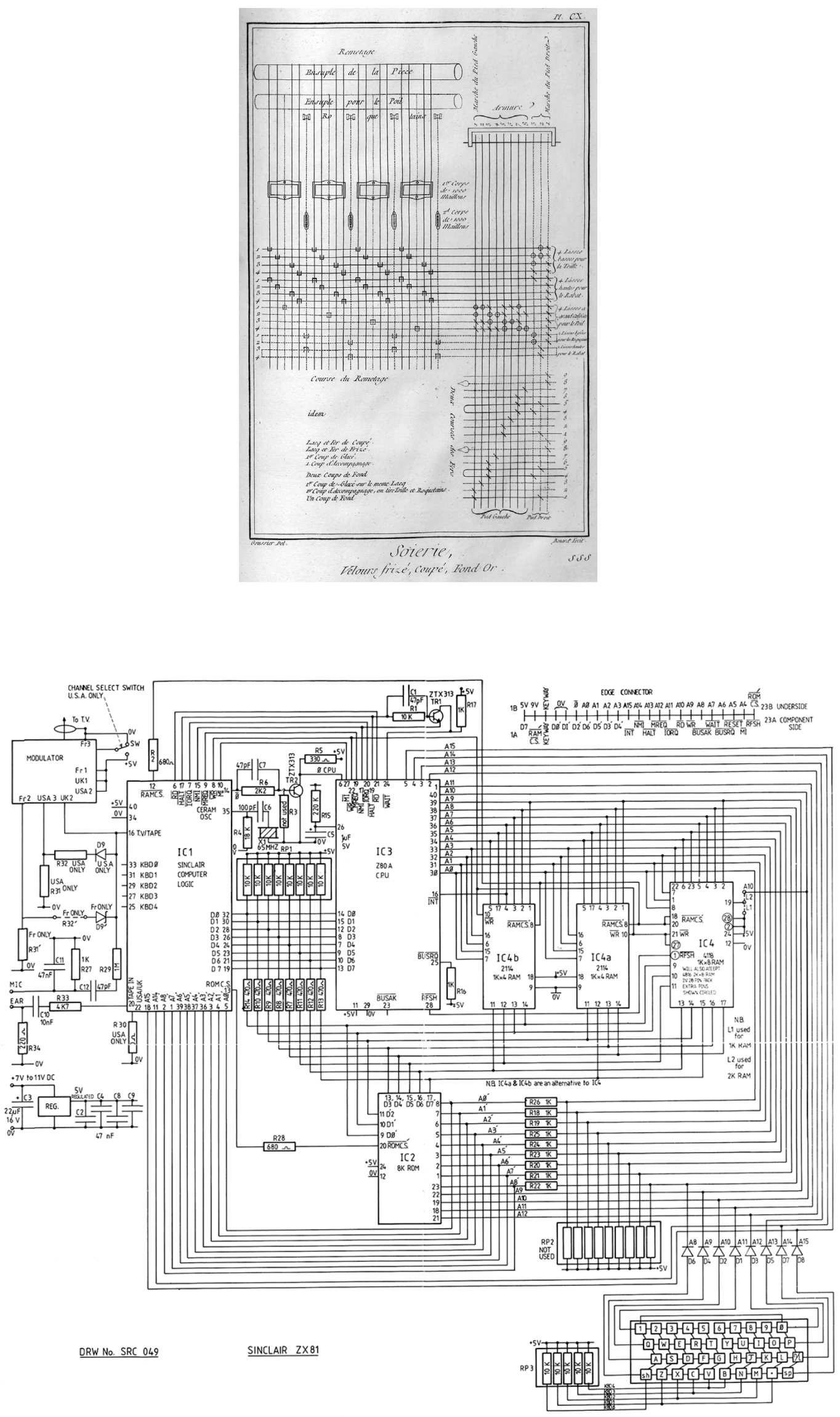


\section{Conclusion}

While in the visual culture of the last centuries a trend has developed which -from realist painting, to photography, to virtual reality- sets the objective of verisimilitude by proposing from time to time devices to support the image that aim at indistinguishable from reality, at the same time, a low-res display mode seems to be developing which finds very solid visual references in the tradition of textiles and mosaics. Alongside an evolution of the computer media, which basically pursue the evanescence of pixels, a trend towards the fruition and production of low-resolution images seems to be spreading further and taking root, which find privileged applications in the playful and videogame field: the 'colored nails' ( fig. 12) invented in 1945 are today among the most popular games, lkea still sells the patented Pyssla in 1962 and some recent applications proposed by Lego for traditional bricks (Mosaic Maker for example) are arousing keen interest. The Minecraft video game uses very low resolution graphics (the protagonist's face is an $8 \times 8$ pixel matrix) and the tablets commonly support pixel art programs for entertainment.

The complexity of the mechanisms of visual perception amply justify this multiplicity of interests and lines of research. In this field of investigation, the History of Representation proves to be a good ally for avoiding the temptation to welcome every technical innovation with a preliminary triumphalism.

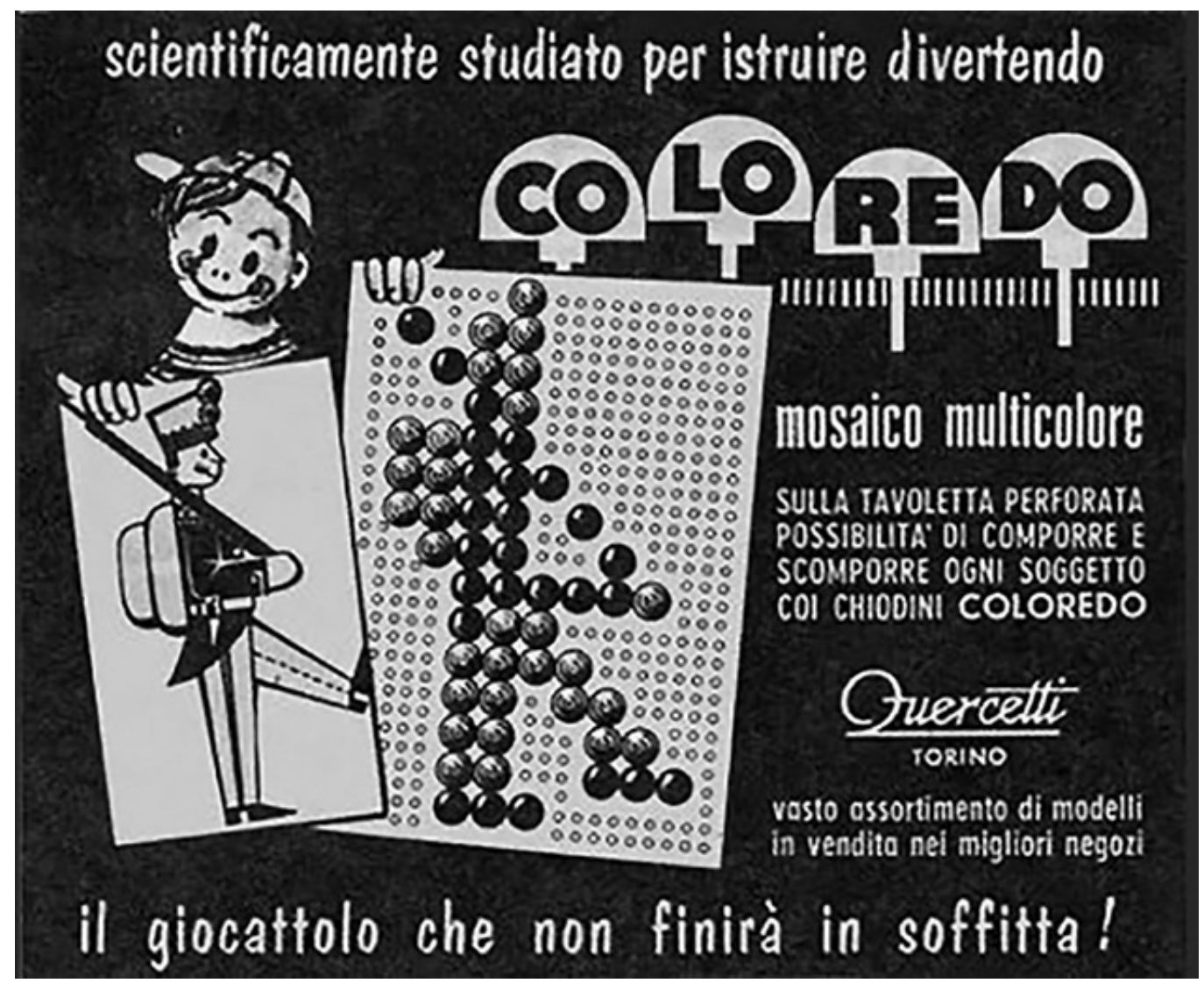

Notes

[I]The Sinclair ZX8I from 1981 and the iMac 21.5 "retina from 2019 are compared, the discounted cost of which is around 1000 euros.

12] Our eye does not distinguish an object that occupies an angular dimension of less than 0 ”, I 'The resolution of a 50 "4K TV screen is not appreciable at a distance greater than $80 \mathrm{~cm}$. The pixels of a recent iPad are invisible from a distance greater than $25 \mathrm{~cm}$.

[3] The inventor, Benjamin Day (1810-1889) was an American publisher. 


\section{References}

De Dillmont Therese (s.d). Alfabeto della Ricamatrice. Lettere, cifre, monogrammi e ornati a punti contati. Mulhouse: Dollfus-Mieg s.d.

Encyclopédie (I75 I-80). Soierie. In Encyclopédie ou Dictionnaire raisonné des sciences, des arts et des métiers. Paris: Le Breton et al.

Fineberg Jonathan (2000). Art Since 1940: Strategies of Being. New York: Harry Abrams Inc.

Gioseffi Decio (1963). Ottica. In Enciclopedia Universale dell'Arte.Venezia-Roma: Ist. per la Collaborazione Culturale.

Harmon Leon (1973). The Recognition of Faces. In Scientific American, vol. 229, n. 5 , pp. 70-83.

Hultén Karl Gunnar Vougt Pontus (1968). The machine, as seen at the end of the mechanical age. New York: The Museum of Modern Art.

Ings Simon (2008). Storia naturale dell'occhio. Torino: Einaudi. Traduzione di Allegra Panini. (Ed. orig. 2007. The Eye. A natural History. London: Bloomsbury.).

Lyon Richard F. (2006). A Brief History of 'Pixel'. In Proceedings of SPIE - The International Society for Optical Engineering, n. 6069.

Maffioletti Silvio, Ruggeri Letizia (2003). Rilevazione, registrazione e valutazione dell'acutezza visiva. Dispensa del Corso di Laurea in Ottica e Optometria Università degli Studi di Milano Bicocca.

McLuhan Marshall (2008). Gli strumenti del comunicare. Milano: il Saggiatore. (Ed orig. 1964. Understanding Media:The Extensions of Man. New York: Mc Graw Hill).

Pinotti Andrea, Somaini Antonio (20 16). Cultura visuale. Immagini sguardi media dispositivi. Torino: Einaudi, pp. $193-220$.

Rood Odgen Nicholas ( 1879 ). Modern Chromatics with Application to Art and Industry. New York: Appleton and Company.

Stulik Dusan C. Kaplan Art (2000). The Halftone. Los Angeles: The Getty Conservation Institute.

Unali Maurizio. (200 I). Pixel di architettura. Roma: Kappa.

Author

Edoardo Dotto, Università degli Studi di Catania, edoardodotto@hotmail.com

To cite this chapter. Dotto Edoardo (2020). Tessere. Gli elementi costitutivi dell'immagine digitale tra arte, scienza e artigianato/Weaving. The building blocks of the digital image between art, science and craftsmanship. In Arena A., Arena M., Brandolino R.G., Colistra D., Ginex G., Mediat D., Nucifora S., Raffa P. (a cura di). Connettere. Un disegno per annodare e tessere. Atti del $42^{\circ}$ Convegno Internazionale dei Docenti delle Discipline della Rappresentazione/Connecting. Drawing for weaving relationships. Proceedings of the 42 th International Conference of Representation Disciplines Teachers. Milano: FrancoAngeli, pp. 3269-3292 